\title{
Oil Seeps from the "Boulganack" Mud Volcano in the Kerch Peninsula (Ukraine - Crimea), Study of the Mud and the Gas: Inferences for the Petroleum Potential
}

\author{
J.P. Herbin ${ }^{1}$, M. Saint-Germès ${ }^{2}$, N. Maslakov ${ }^{3}$, E.F. Shnyukov ${ }^{3}$ and R. Vially \\ 1 Institut français du pétrole, IFP, 1-4 avenue de Bois-Préau, 92852 Rueil-Malmaison Cedex - France \\ 2 Beicip-Franlab, 232 avenue Napoléon Bonaparte, 92500 Rueil-Malmaison - France \\ 3 National Museum of Natural History, 15 Khmelnitsky Street, 01030, Kiev - Ukraine \\ e-mail: j-paul.herbin@ifp.fr - macha.saint-germes@beicip.fr - nikalmas@mail.ru - roland.vially@ifp.fr
}

\begin{abstract}
Résumé - Indices du volcan de boue "Boulganack" dans la péninsule de Kerch (Ukraine Crimée), étude de la boue et du gaz : conséquences pour le potentiel pétrolier - De par leur origine profonde, les sédiments et les gaz rejetés par les volcans de boue sont des indices riches d'information pouvant être utilisés par les compagnies pétrolières lors des phases d'exploration, l'étude des paramètres géochimiques des fluides permettant d'évaluer et préciser le potentiel pétrolier régional.

L'activité des volcans de boue est particulièrement intense dans les régions du Caucase, d'ouest en est : péninsule de Kerch en Crimée, Kuban en Russie et Azerbaïdjan, cette activité onshore se prolongeant en offshore : mer Noire à l'ouest et mer Caspienne à l'est.

Une méthodologie d'échantillonnage et des protocoles analytiques ont été développés sur les volcans de boue onshore de ces régions et plus particulièrement appliqués sur le volcan de boue de Boulganack dans la péninsule de Kerch.

Trois missions ont été organisées par l'IFP en 2000, 2001 et 2002 afin de récupérer des échantillons de boue et de gaz avec la contribution du Museum National d'Histoires Naturelles de Kiev. L'objectif était, d'une part, l'étude des variations spatiales des effluents des différents évents du volcan de Boulganack et, d'autre part, la réalisation de prélèvements hebdomadaires pour observer les variations temporelles dans les différents évents.

Des techniques d'échantillonnage ont été developpées pour récupérer des sédiments non pas directement à la surface de l'évent mais en descendant un appareillage par gravité dans la cheminée du volcan de boue de façon à éviter les problèmes de biodégradation de surface qui peuvent altérer la qualité de l'échantillon. De même, pour les gaz émis sur les lacs de boue, un système a été mis au point pour créer une ligne de fluide depuis le lieu d'émission jusqu'à la terre ferme. Deux des évents de Boulganack atteignent en effet de grandes profondeurs : $40 \mathrm{~m}$ à Pavlov et presque $20 \mathrm{~m}$ à Oldenburg.

En ce qui concerne l'étude des gaz, les proportions de $\mathrm{N}_{2}, \mathrm{CO}_{2}, \mathrm{H}_{2} \mathrm{~S}, \mathrm{O}_{2}$ et hydrocarbures (méthane à butane) ont été mesurées. La composition des gaz varie d'un évent à l'autre. La majorité des évents de Boulganack rejette $90 \%$ de méthane et $10 \%$ de $\mathrm{CO}_{2}$ avec une très faible présence d'hydrocarbures plus lourds (éthane) uniquement localisés sur l'évent d'Andrusov. Pavlov expulse autant de $\mathrm{CO}_{2}$ que de méthane (50/50). De l'azote est quelquefois également enregistré (Pavlov, Obrudchev, Central Lake).
\end{abstract}


Ces rejets sont interprétés comme étant thermogéniques (sécheresse du gaz, peu d'hydrocarbure). Comparé à cette grande variabilité spatiale (d'un évent à l'autre), les variations temporelles (enregistrement hebdomadaire) sont beaucoup plus faibles et peu significatives.

Les quantités d'hydrocarbures libres, dans les sédiments extrudés par les volcans de boue de la province de Kerch comparées à ceux d'Azerbaïdjan montrent des teneurs beaucoup plus faibles dans les volcans de boue de Crimée. Les quantités d'hydrocarbures libres dans la boue semblent en outre être un critère déterminant permettant de classer les provinces pétrolières. Dans la péninsule de Kerch, les analyses par chromatographie des hydrocarbures des échantillons de surface présentent un fort taux de dégradation. En revanche, ceux prélevés en profondeur dans les gryphons ne sont pas biodégradés et ont une signature identique à celle de la formation du Maïkop avec une matière organique d'origine terrestre.

La modélisation de la génèse des hydrocarbures confirme le rôle principal de la formation du Maïkop comme source effective des hydrocarbures. Toutefois, dans la péninsule de Kerch, les roches mères de type III seraient surtout favorables à la génèse de gaz.

\begin{abstract}
Oil Seeps from the "Boulganack" Mud Volcano in the Kerch Peninsula (Ukraine Crimea), Study of the Mud and the Gas: Inferences for the Petroleum Potential - Mud volcanoes act as prospecting indices in the exploration of oil and gas deposits with gases and muds excreted. A methodology and an analytical protocol have been developed in order to classify the petroleum provinces according to the geochemical information available from the mud volcanoes. Such a study allows us to evaluate the potential of the petroleum system beneath.
\end{abstract}

The Crimean-Caucasus region is renowned for mud volcano activity with well-known areas from west to east: Kerch Peninsula, Kuban and Azerbaijan.

A methodology concerning the geochemical sampling and analysis of the mud volcanoes located onshore was applied to the Kerch Peninsula. Three field trips were organised by IFP in 2000, 2001 and 2002 in order to collect geochemical data, in agreement with the Museum of National History in Kiev. During these geological and geochemical surveys particular attention was given to the Boulganack mud volcano, which is a favourable site for the study of mud and gas samples due to the variety of the types of the vents.

Specific tools were built in order to take samples of mud, up to $20 \mathrm{~m}$ deep in the vents, and gas more than 25 m away from the bubbling point in safe conditions in the deep mud lakes. Moreover, monitoring of the sampling of the gas was undertaken on the Boulganack mud volcano for one year in order to study the variation in the composition of the gas in time and space in the various vents.

The proportions of nitrogen, carbon dioxide and hydrocarbons (methane to ethane) were measured. The vents of the Boulganack mud volcano present about $90 \%$ of methane and $10 \% \mathrm{CO}_{2}$, with a few percent of heavier hydrocarbons in one particular vent: Andrusov. Pavlov expelled more $\mathrm{CO}_{2}(25 \%$ to $40 \%)$, with the greatest temporal variations. Only Obrudchev expels as much carbon dioxide as methane (50/50). Sometimes, nitrogen was also measured (Pavlov, Obrudchev and Central Lake).

The high dryness of the gas implies a loss of heavy hydrocarbon compounds relative to a typical thermogenic gas. Chemical gas compounds are highly dependent from one vent to the other.

The comparison of the quantity of hydrocarbon included in the mud released from the mud volcanoes of the Kerch Peninsula and those of Azerbaijan (used as a reference) shows very little hydrocarbon in the mud from the mud volcano in the Crimea, whereas accumulations of hydrocarbons exist in the fluids expelled from mud volcanoes in Azerbaijan. In fact, the ranking of the petroleum provinces is linked to the occurrence of the free hydrocarbons in the mud excreted by mud volcanoes. Analysis by chromatography of the saturated hydrocarbons presents a high degree of biodegradation when the samples are taken at the surface. When they are taken with the core barrel at greater depth in the vents, the hydrocarbons are preserved with a typical continental origin which can be compared with the organic matter of the Maykop formation.

The modelling of the hydrocarbon window geohistory confirms that the hydrocarbons are mainly produced within the lower Maykop. The generation of gas is favoured, in agreement with the quality of the type III source rocks in this western part of the Caucasus. 


\section{INTRODUCTION}

Mud volcanoes bring to the surface sediments, fluids and gas that may come from deep horizons, and so the sampling and studying of these products may help to understand better the petroleum system in frontier petroleum exploration areas.

The Crimean-Caucasus region is renowned for mud volcano activity with well-known areas from west to east: Kerch Peninsula, Kuban and Azerbaijan.

The Taman and Kerch Peninsulas (Fig. 1) are located between the Caucasus in the east (Russia) - which is an incratonic range with a tertiary evolution integrated within the alpine compression - and the Crimea (Ukraine) in the west, with a complicated and active structuration since the end of the Jurassic.

The Indolo-Kuban basin corresponds to a fore deep in front of the Great Caucasus. The depression of Taman and Kerch, built up during the Oligocene-Miocene - at the edge of the hercynian Scythian platforms (Russia) contains about 85 oil and gas fields on both sides of the strait as well as unexplored structures in the Black Sea (Fig. 2).

In the Kerch Peninsula, the older known sediments are carbonates of Jurassic age. The series of carbonate deposit continues during the Cretaceous, which remains a possible target as potential source rock [1, 2]. During the OligoceneMiocene the deposition of the Maykop Formation contains sandstone reservoirs which play an important role in petroleum

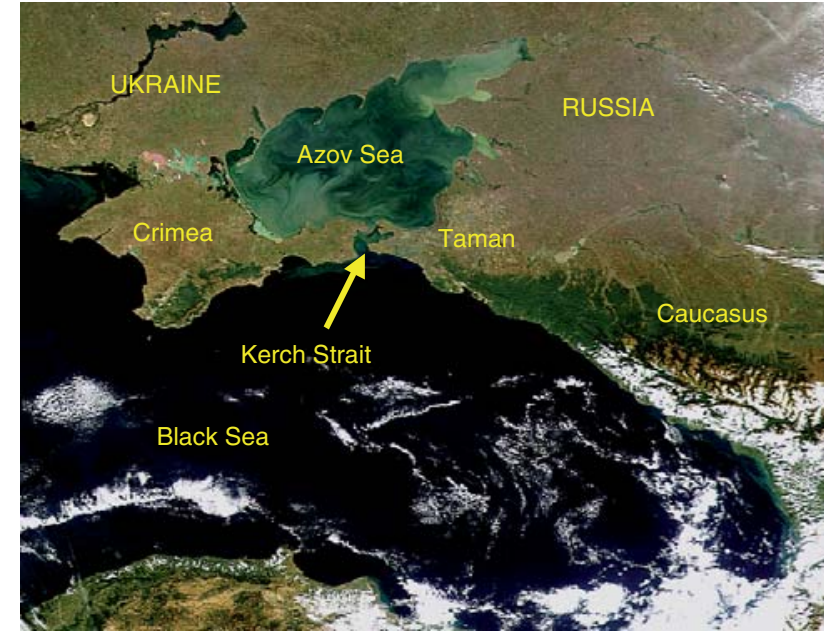

Figure 1

Location of the Kerch Strait between the Azov Sea and the Black Sea.

exploration. The quality of these reservoirs increases in the eastern part of the Kerch Peninsula. The OligoceneMiocene deposits also contain clays which are potential source rocks with a transition between the marine and continental organic matter from the lower Maykop to the upper Maykop. The thickness of the Maykop series can reach up to $6000 \mathrm{~m}$ in the paleo depression of the Indolo-Kuban, the

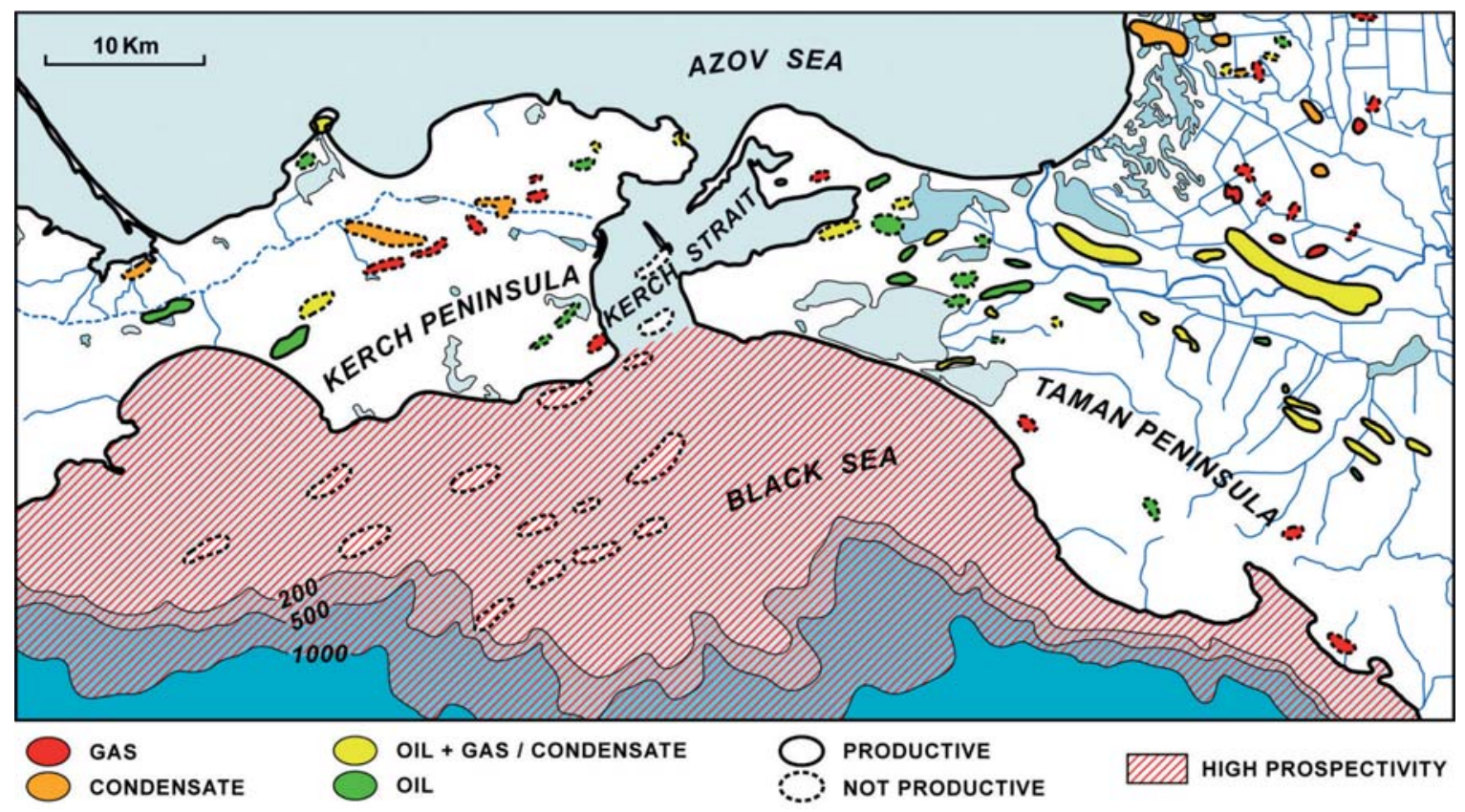

Figure 2

Oil and gas fields in the Kerch Strait (Kerch Peninsula/Ukraine and Taman Peninsula/Russia).

Red $=$ oil field , orange $=$ condensate, yellow $=$ oil gas, green $=$ gas .

Notice the unexplored offshore structures in the Black Sea. 


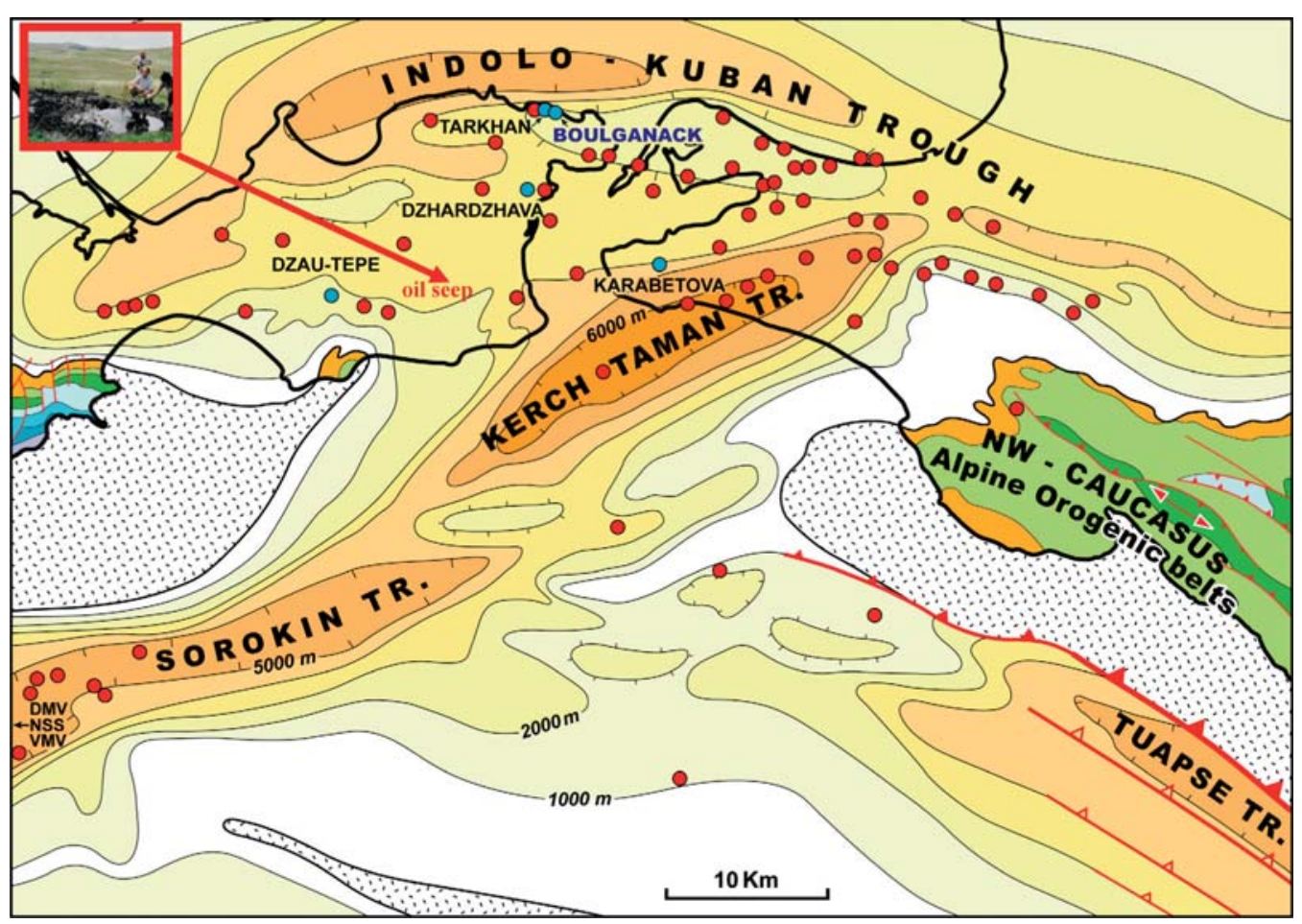

Figure 3

Location of the mud volcanoes onshore correlated with the thickness of the Maykop formation in the Kerch Strait [4] Red dots represent the location of the mud volcanoes.

In blue, the mud volcanoes mentioned in the text.

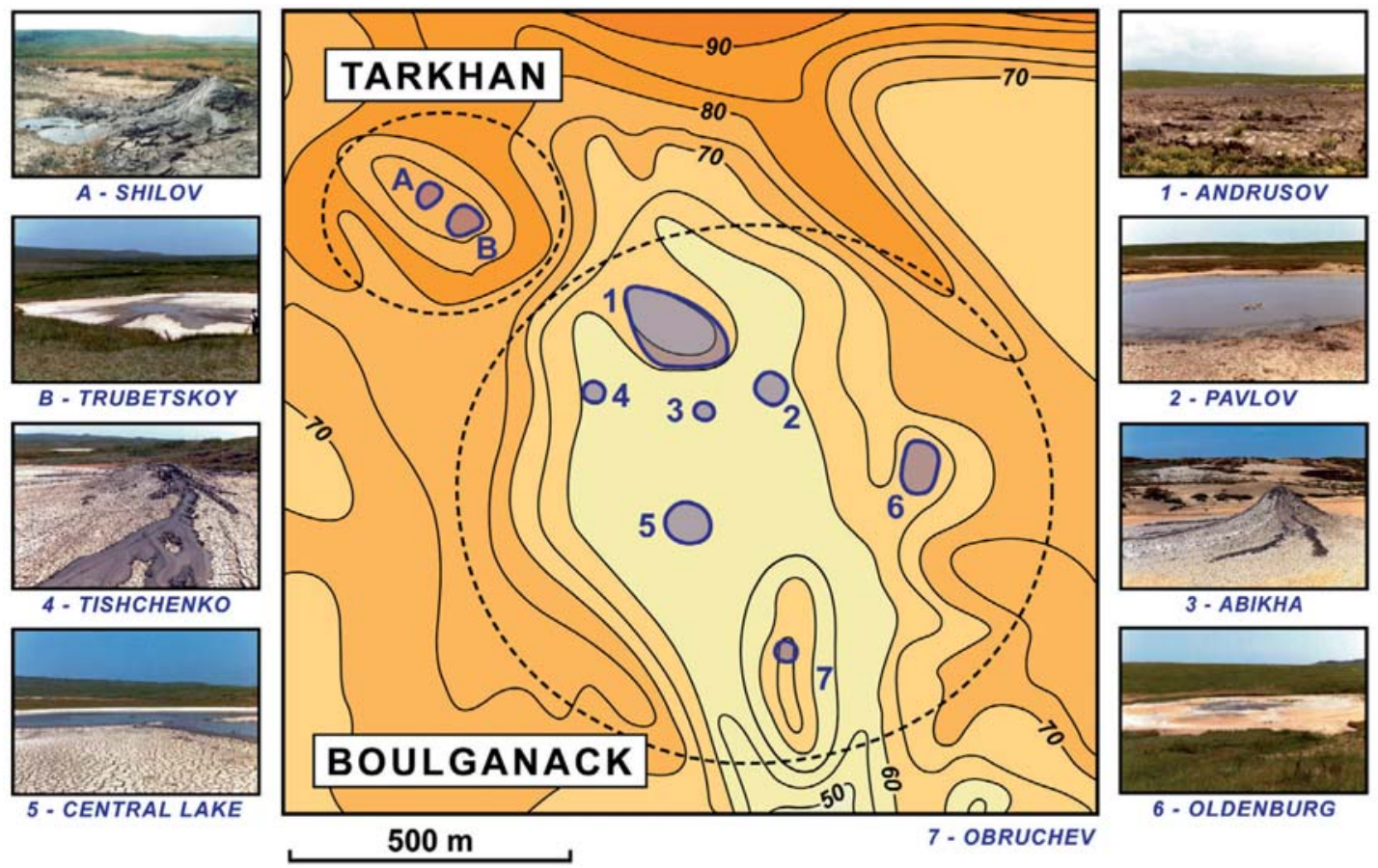

Figure 4

Localisation of the vents on the Boulganack and Tarkhan mud volcanoes. 
Sorokin and the Tuapse troughs (Fig. 3). The mud volcanoes are generally located in the vicinity of the depocenters of the Maykop series. All the mud volcano areas are characterised by high pore fluid pressure and in the Indolo-Kuban Basin pore pressure may exceed more than twice the hydrostatic pressure [3]. The Boulganack mud volcano was chosen due to the various types of vents existing on the site: gryphons, satellite craters, flank vents and small lakes (salses).

The Boulganack mud volcano with a form of calderas (Fig. 4) is characterised by relatively weak and continuous activity $[5,6]$. It is strongly affected by the presence of water-saturated layers in the upper part of the sequence [7]. Numerous vents spit out small amounts of gassy mud and water. In a unique site the Boulganack mud volcano shows different types of morphology of vents:
- Andrusov (No. 1 in Fig. 4 / N 45 25'39” - E 36²8'41") is the main crater. It shows gradual and progressive outflows of solid material spreading as a fresh circular cake of mud covering an area of about 2000 square metres (Fig. 5). This outflow of mud in connection with the feeder channel includes numerous pieces of solid rock fragments. At the periphery of the central vent, smaller vents exist, though most of them are inactive while very few gas and liquid exhausts occur (Fig. 6). During the one year of monitoring, between June 2001 and June 2002, the sampling site of the Andrusov vent moved following the migration of the active vents along the flank (Fig. 7). As a rule, the Boulganack mud volcano is rather quiet, but on 1st September 1986, the Andrusov mud cone produced a triple violent eruption reaching $20 \mathrm{~m}$ in height.

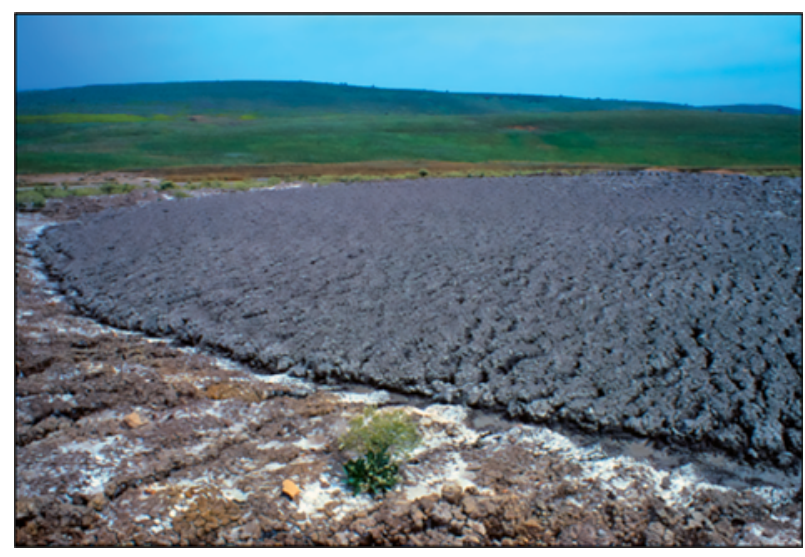

Figure 5

In 2001-2002 the extrusion of the mud on Andrusov (main crater) reached $20 \mathrm{~m}$ in diameter.

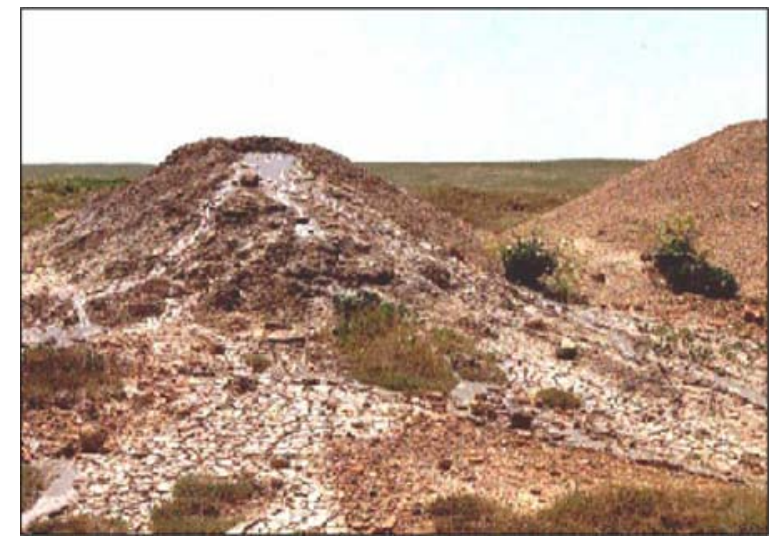

Figure 6

Active and dead vents on the Andrusov flank.
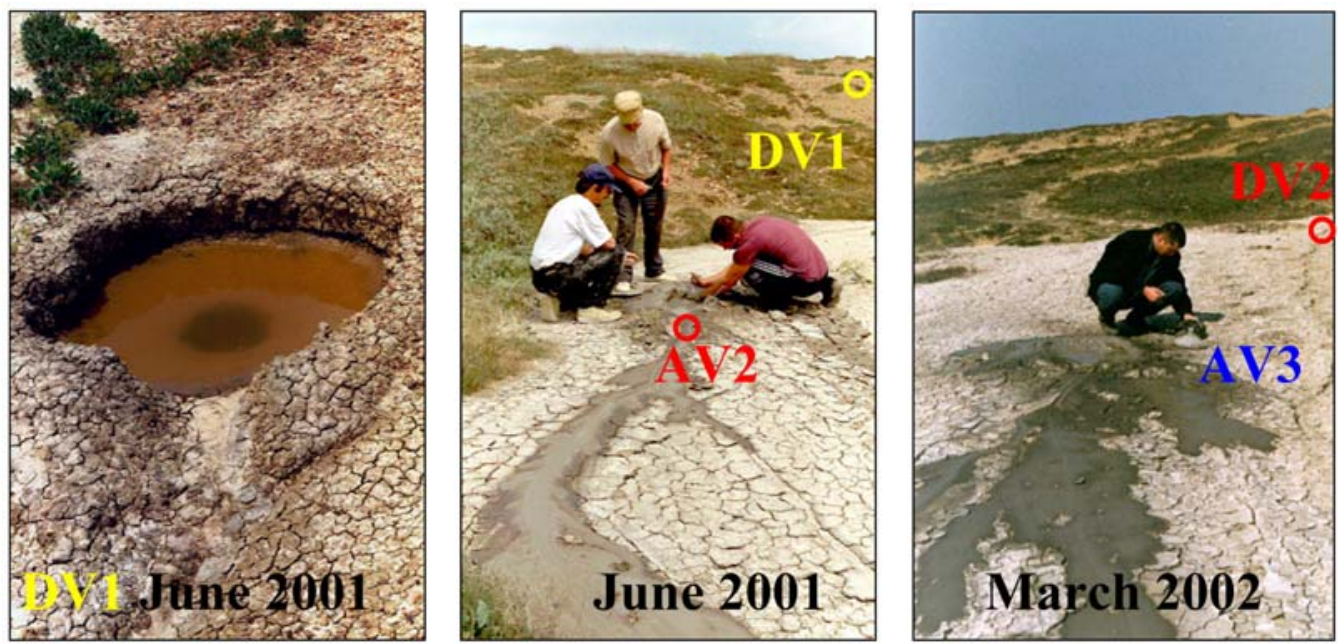

Figure 7

Migration of the satellite vents on the Andrusov flank showing their temporary activity: in June 2001 gas sampling $10 \mathrm{~m}$ away from the old dead vent (DV).

In March 2002 the active vent (AV) was again located $10 \mathrm{~m}$ further downward. 


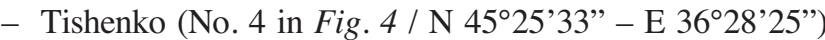
and Abikha (No. 3 in Fig. 4 / N 45 $25^{\prime} 33^{\prime \prime}$ - E 36 $28^{\circ} 42^{\prime \prime}$ ), located at the periphery of the main crater (Andrusov), have a classical cone shape about $1.5 \mathrm{~m}$ high. They are characterised by the absence of solid rock fragments and emit mud, water and gas with a bubble of $10 \mathrm{~mm}$ in diameter every $2 \mathrm{~s}$.

- Central Lake (No. 5 in Fig. 4 / N 45 25'21”' - E 36²8'39”) and Pavlov (No. 2 in Fig. 4 / N 45 25'34" - E 36 $28^{\circ}$ '44”) are satellite craters with a lake (salse) and a bubbling point and some smaller gas vents at the border (Central Lake). They emit mainly water and gas (one bubble of $120 \mathrm{~mm}$ in diameter every $8 \mathrm{~s}$ ). In March 2002, during a survey using an inflatable dinghy, it was possible to sound the shape of the lakes and to determine the depth of the stable substratum. Pavlov has nearly vertical edges with the maximum depth of the sounding line being around $38 \mathrm{~m}$, while in Central Lake it reaches only $6 \mathrm{~m}$ (Fig. 8).

- Oldenburg (No. 6 in Fig. 4 / N 4525'28” - E 36²9'07’) is also a collapsed area characterised by more than about ten puddles, generally of one to two metres in diameter, with vertical sides which reach a depth of twenty metres. Only a few of them emit bubbling of gases, which on the whole is equivalent to a bubble of $100 \mathrm{~mm}$ in diameter every $10 \mathrm{~s}$.
- Obrudchev (No. 7 in Fig. 4 / N 45 25'08” - E 36 28'50”) has very little activity, with no overflowing of mud, very few exhausts of water, and only some small bubbles of gas (equivalent to a bubble of $8 \mathrm{~mm}$ in diameter every $2 \mathrm{~s})$.

The Boulganack mud volcano is close to the Tarkan mud volcano, which presents two main vents: a classical cone, "Shilov" (A), and a collapsed area with salse, "Trubetskoy" (B).

The geochemical study was only focused on the different vents of the Boulganack mud volcano.

\section{SAMPLING}

Several types of procedure were used in order to sample the natural gas seepage directly from the bubbling on the active gryphons.

A sealed glass tube in which the vacuum has been previously released allows sampling of $10 \mathrm{cc}$ of gases which are necessary to analyse the global chemical proportions. This only requires threading the protective cap of the tubes through a needle located at the top of a bell-shaped glass cap (Fig. 9). Generally, several samples are taken from the same gryphons in order to test the reproducibility of these analyses.
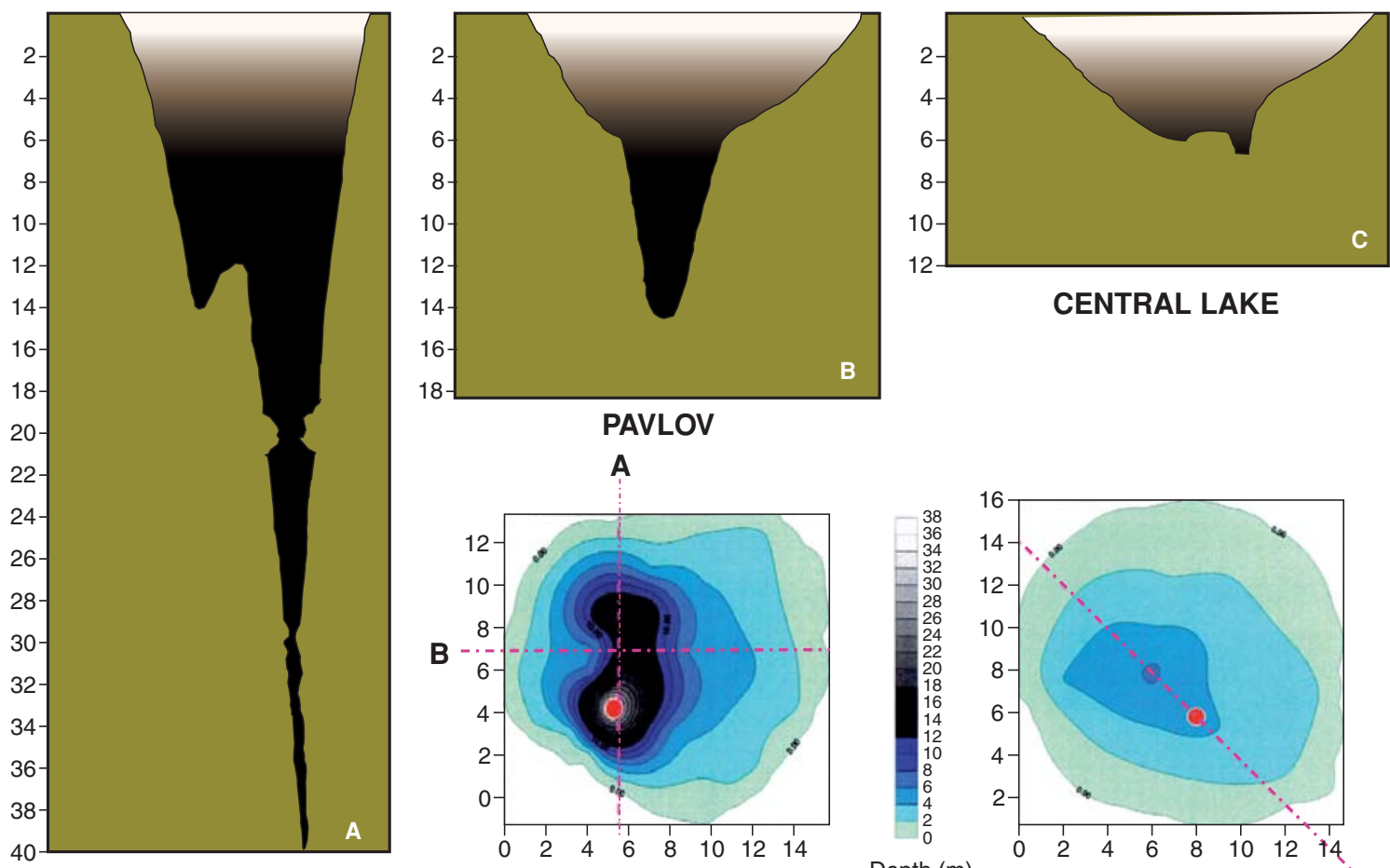

CENTRAL LAKE
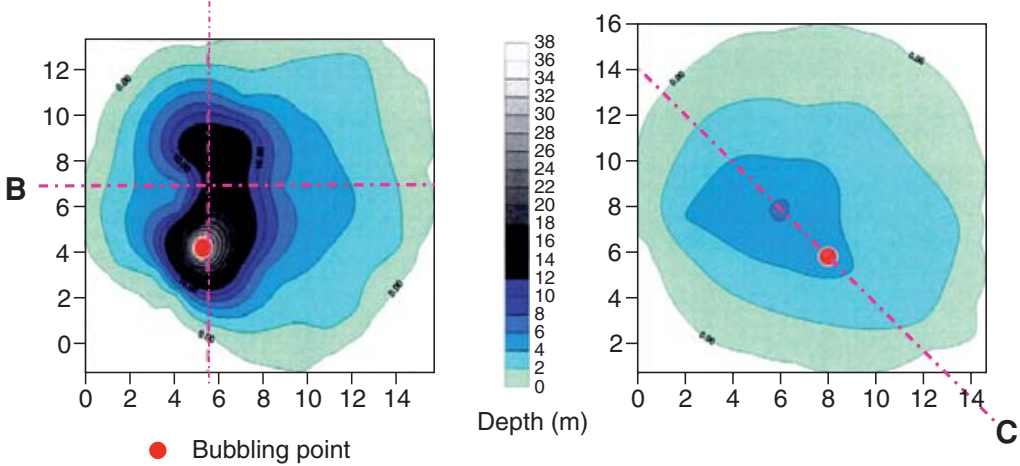

Figure 8

Cross-section through the Pavlov and Central Lake vents showing the depth of the stable substratum (data obtained during a survey in March 2002). 


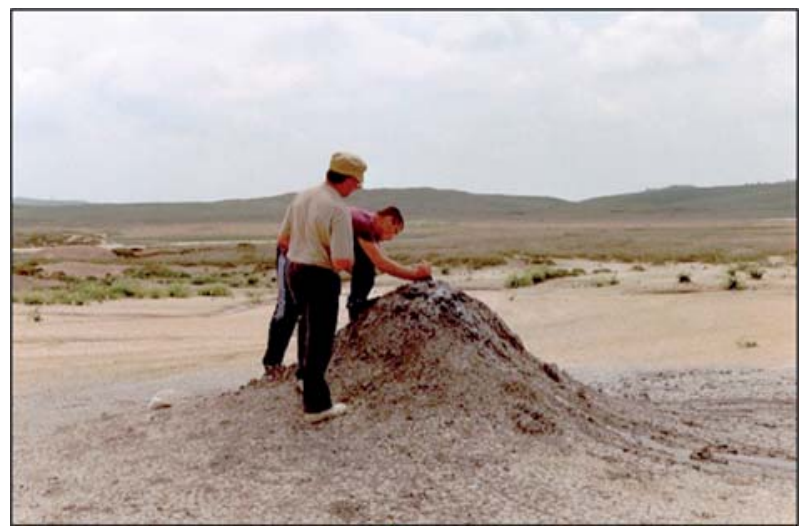

Figure 9

Gas sampling on Abikha during the one-year monitoring.
During the one-year monitoring, the weekly sampling consisted of taking gas samples in sealed glass tubes from every vent of the Boulganack mud volcano, i.e. Obrudchev, Oldenburg, Great Lake, Pavlov, Abikha and Tishenko, and several secondary vents characterised by temporary activity on Andrusov. Some gaps in the monitoring existed due to the bad meteorological conditions, particularly in winter.

For the lakes, a technique was developed in order to recover the gas from the edge in safe conditions. The gas bubbling at the surface of the lakes was headed up with a floating jar and then moved in a flexible tube several tens of metres long (Figs. 10-12). This methodology, named “Chapka Monomaha” ("Tsar's hat"), was, in fact, similar to the technology used in the 1930s when local people recovered the gases of the Central Lake for industrial purposes in order to dry the mud and to recover boron which, with
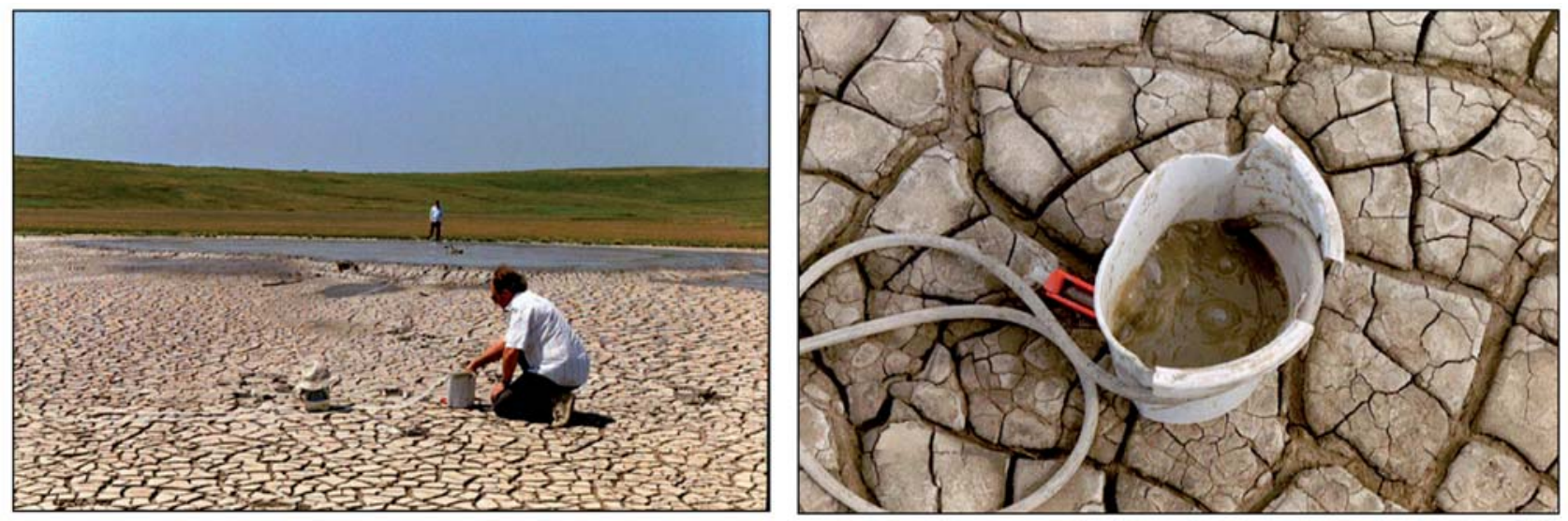

Figure 10

Central Lake: gas sampling with the "Chapka Monomaha" $25 \mathrm{~m}$ away from the bubbling point occurring at the centre of the lake.
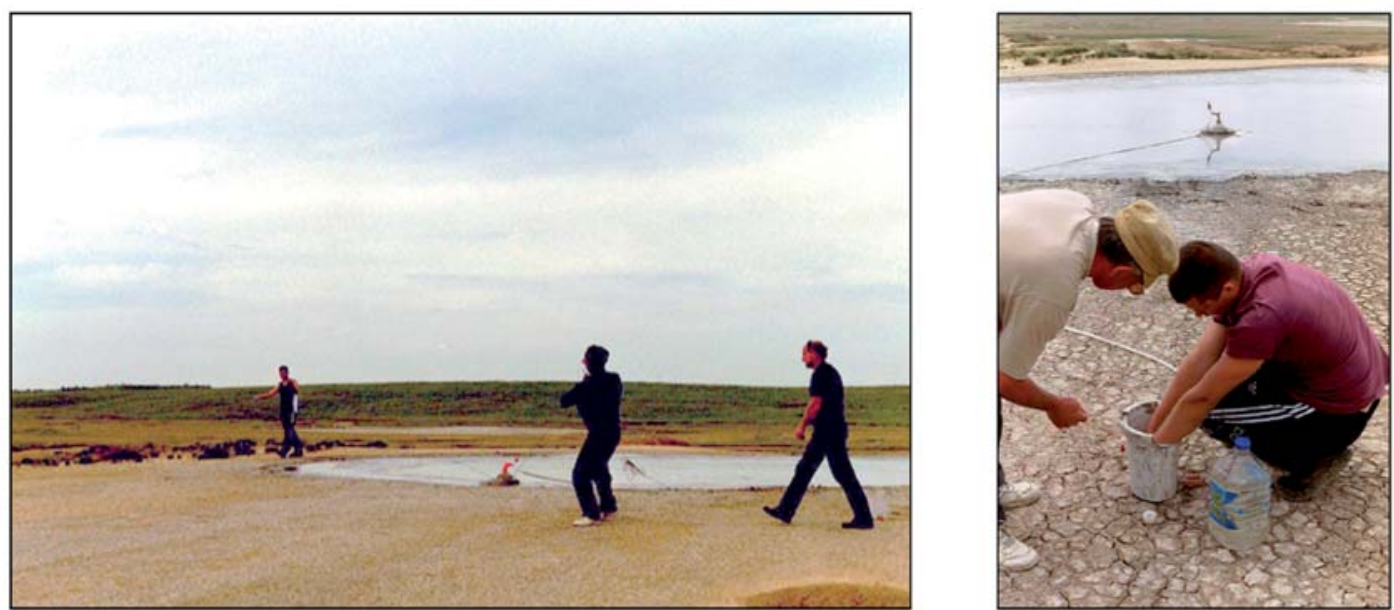

Figure 11

Launch of the "Chapka Monomaha" and sampling of gas samples $10 \mathrm{~m}$ away from the bubbling point on Pavlov. 


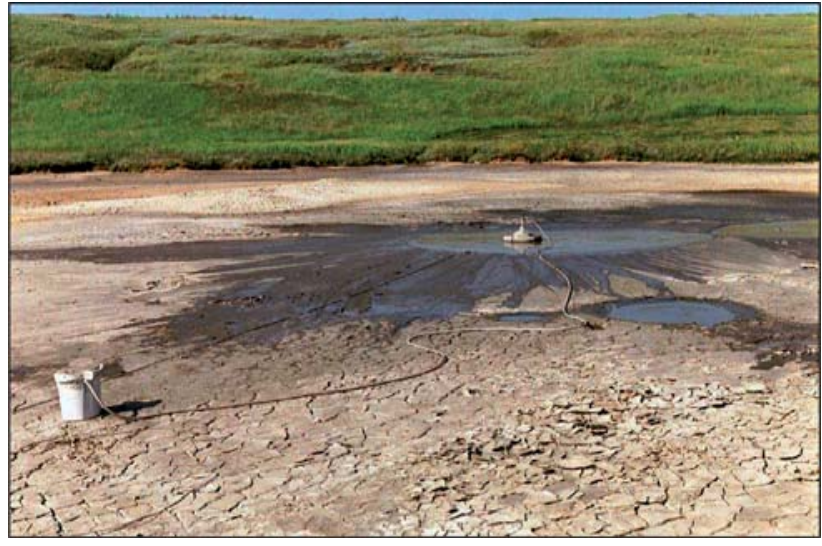

Figure 12

Gas sampling with the "Chapka Monomaha" from one of the Oldenburg pools.

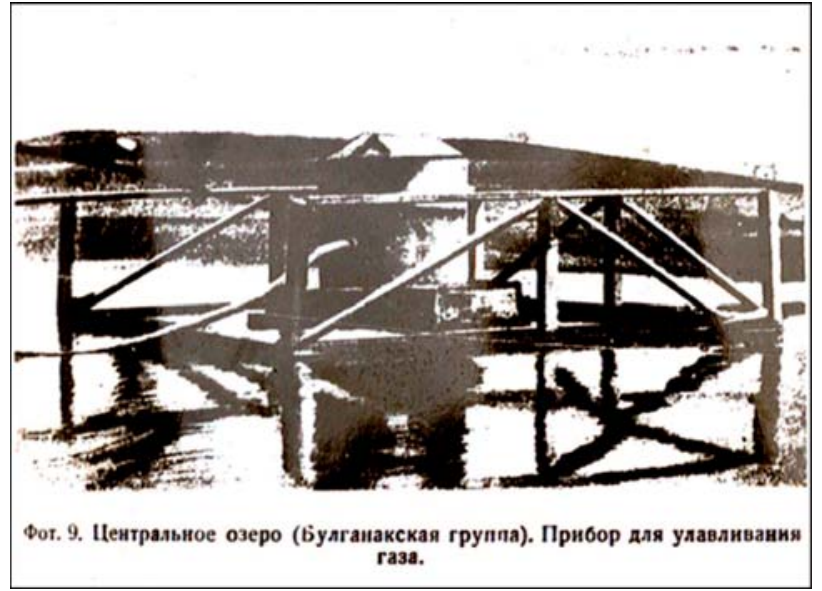

Figure 13

Industrial recovery of the gas from the bubbling point on Central Lake in the 1930s. iodine, is of high content in the mud flowing out of the mud volcanoes (Fig. 13). The "Chapka Monomaha" was also used to estimate the outflow of gas coming from the main vents.

Concerning the sampling of the mud, it is necessary to avoid the material taken straight from the surface of the vents (i.e. in the layer within the first few metres) in order to obtain representative information concerning the free hydrocarbons contained in the mud.The first cause which modifies the representativeness of the samples can be called "the cream effect". Depending on the outflow of the mud and the size of the various vents, a concentration of the elements contained in the mud at the surface is possible due to the alternation of rainy and dry seasons. A sample taken at the surface represents the balance between the outflow, the evaporation and the rain. The "cream effect" is also the consequence of the segregation of the products according to their density: the thin layer of hydrocarbon at the surface of the gryphon is consequently not representative of the outflow of free hydrocarbons excreted from underneath.

A second cause affects the quality of the hydrocarbons excreted due to the microbial activity which grows within the mouth of the mud volcanoes. In fact, the proto-life colonises the surface and walls within the gryphons. Due to this bacterial colonisation, the hydrocarbons are highly biodegraded.

In order to avoid both the problems of biodegradation and the "cream effect", a core barrel composed of a tube $30 \mathrm{~cm}$ in length and $3 \mathrm{~cm}$ in diameter with a protective cap at the top was made (Fig. 14). The core barrel is ballasted and goes down into the liquid mud by itself, reaching the stable substratum at maximum depth (the length of the ropes being $50 \mathrm{~m}$ ). The protective cap at the top is opened when the core
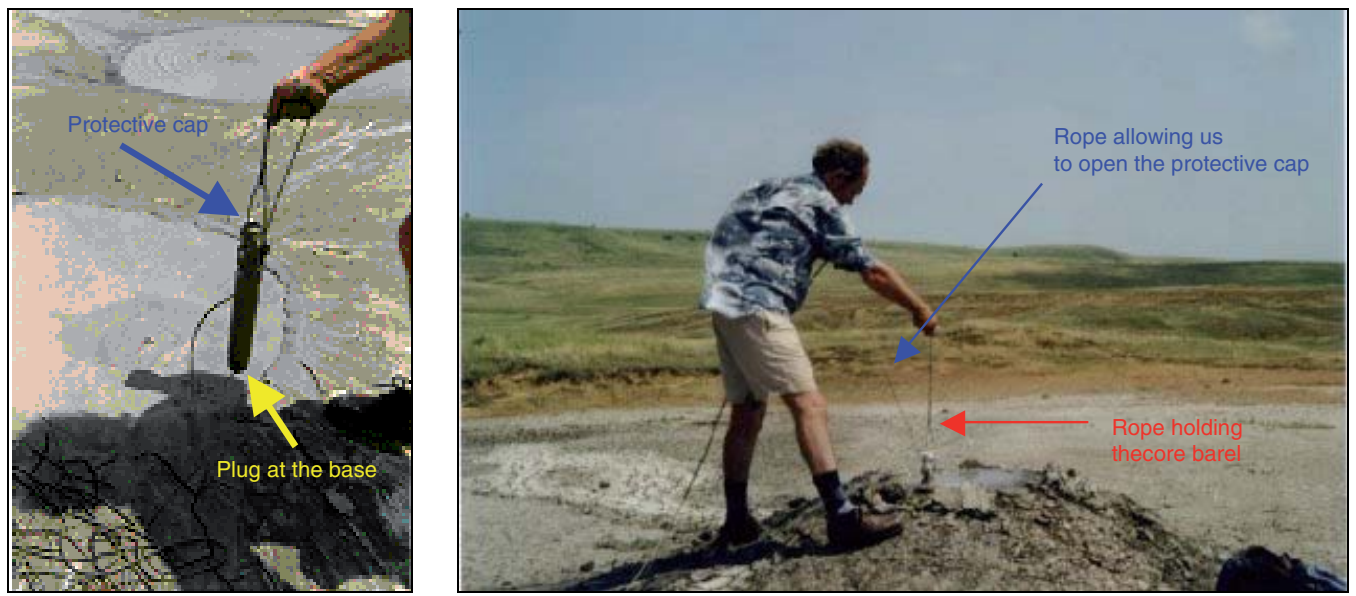

Figure 14

Core barrel enables us to sample mud at the deepest point of the vent (left: Oldenburg/19 m deep; right: Tischenko No. $4 / 3 \mathrm{~m}$ deep). 
barrel has reached its maximum depth, i.e. when the passage inside the vents is too narrow or tortuous for the core barrel. After the rising, the core barrel is drained through a plug at the base and only half of the material is retained, This is located in the lower part of the core barrel in order to avoid contamination and mixing with the surface mud during the rising of the core barrel. With such a device, samples of mud were taken in the Boulganack mud volcano from up to $38 \mathrm{~m}$ depth in the Pavlov Lake and $19 \mathrm{~m}$ in one of the Oldenburg pools.

\section{GAS COMPOSITION AND ASSESSMENT OF THE VENT FLUX IN THE BOULGANACK MUD VOLCANO; COMPARISON WITH THE ACTIVITY OF OTHER MUD VOLCANOES IN THE VICINITY}

During a period of one year, between June 2001 and June 2002, samples of gas, collected in vacutainers every week from each vent selected, were regularly sent to the geochemical laboratory of IFP in order to be analysed. The proportions of $\mathrm{N}_{2}, \mathrm{CO}_{2}, \mathrm{H}_{2} \mathrm{~S}, \mathrm{O}_{2}$ and of hydrocarbons from methane to ethane were measured by gas chromatography using a
Varian chromatograph. The surfaces of the peaks on the chromatogram are a function of the quantity of the compounds. A calibration is realised according to the response coefficient of the detector to each of the gases and the whole is standardised to obtain the global composition.

The various vents of the Boulganack mud volcano contain generally about $90 \%$ methane and $10 \% \mathrm{CO}_{2}$ : Oldenburg, Abihka, Tishenko $1 \& 4$, Andrusov $2 \& 6$, and Central Lake (Fig. 15). Heavier hydrocarbons like $\mathrm{C}_{2} \mathrm{H}_{6}$ ethane occurred only in the satellite vents of the main crater Andrusov (vents Nos. 1, 4, 5 and 7) where plastic mud extrudes.

Pavlov, and above all Obrudchev, expelled more $\mathrm{CO}_{2}$ ( $25 \%$ to $40 \%$ ). Central Lake has the greatest temporal variations. Obrudchev expelled as much carbon dioxide as methane (50/50).

Puffs of nitrogen were occasionally measured in Pavlov, Obrudchev and Central Lake.

Chemical gas compounds are highly dependent from one vent to the other (Fig. 15). Chemical heterogeneities, a few metre scales geographically, imply complex fluid circulation near the surface. On the other hand, gas compound variations versus time seem to be smaller, and not really significant.

\begin{tabular}{|c|c|c|c|c|c|c|}
\hline $\begin{array}{c}\text { Boulganack } \\
\text { Individual Gryphons } \\
\text { and Salses }\end{array}$ & $\begin{array}{c}\text { Observation made by } \\
\text { the authors during } \\
\text { two field trips organised } \\
\text { in June } 2001 \text { and March } 2002\end{array}$ & $\begin{array}{l}\text { Vent Flux } \\
\mathbf{m}^{3} \mathbf{y}^{-1}\end{array}$ & $\begin{array}{l}\mathbf{C}_{2} \mathrm{H}_{6} \\
\mathrm{~m}^{3} \mathrm{y}^{-1}\end{array}$ & $\begin{array}{c}\mathrm{CH}_{4} \\
\mathrm{~m}^{3} \mathbf{y}^{-1}\end{array}$ & $\begin{array}{c}\mathrm{CO}_{2} \\
\mathbf{m}^{3} \mathbf{y}^{-1}\end{array}$ & $\begin{array}{c}\mathbf{N}_{2} \\
\mathbf{m}^{3} \mathbf{y}^{-1}\end{array}$ \\
\hline Andrusov vents $1,4,5 \& 7$ & $\begin{array}{c}\text { one bubble of } 10 \mathrm{~mm} \text { diameter } \\
\text { every } 3 \mathrm{~s}\end{array}$ & 6 & 0.1 & 5.6 & 0.1 & 0.09 \\
\hline Andrusov vents $2 \& 6$ & $\begin{array}{c}\text { one bubble of } 10 \mathrm{~mm} \text { diameter } \\
\text { every } 3 \mathrm{~s}\end{array}$ & 6 & $\mathbf{0}$ & 5 & 1 & 0.03 \\
\hline Tischenko ${ }^{\text {vent } 1}$ & $\begin{array}{c}\text { one bubble of } 10 \mathrm{~mm} \text { diameter } \\
\text { every } 3 \mathrm{~s}\end{array}$ & 6 & $\mathbf{0}$ & 5,8 & 0.2 & 0.02 \\
\hline Tischenko ${ }^{\text {vent } 4}$ & $\begin{array}{l}\text { one bubble of } 10 \mathrm{~mm} \text { diameter } \\
\text { every } 2 \mathrm{~s}\end{array}$ & 8 & $\mathbf{0}$ & 7 & 1 & $\mathbf{0}$ \\
\hline Pavlov & $\begin{array}{l}\text { nine bubbles of } 28 \mathrm{~mm} \\
\text { every second (with the Chapka) }\end{array}$ & 3262 & $\mathbf{0}$ & 2172 & 961 & 129 \\
\hline Abihka & $\begin{array}{l}\text { one bubble of } 10 \mathrm{~mm} \text { diameter } \\
\text { every } 2 \mathrm{~s}\end{array}$ & 8 & $\mathbf{0}$ & 7 & 1 & 0.01 \\
\hline Central Lake & $\begin{array}{c}\text { one bubble of } 120 \mathrm{~mm} \text { diameter } \\
\text { every } 8 \mathrm{~s}\end{array}$ & 3567 & $\mathbf{0}$ & 2889 & 202 & 476 \\
\hline Oldenburg all vents & $\begin{array}{l}\text { all pools are equivalent to a bubble } \\
\text { of } 100 \mathrm{~mm} \text { diameter every } 10 \mathrm{~s}\end{array}$ & 1651 & $\mathbf{0}$ & 1473 & 178 & 0 \\
\hline Obruchev & $\begin{array}{c}\text { one bubble of } 8 \mathrm{~mm} \text { diameter } \\
\text { every } 2 \mathrm{~s}\end{array}$ & 4 & 0 & 2 & 2 & 0.09 \\
\hline
\end{tabular}

\begin{tabular}{c|c|c|c|c|c}
\hline Boulganack Vent Flux & All gas & $\mathrm{C}_{2} \mathrm{H}_{6}$ & $\mathrm{CH}_{4}$ & $\mathrm{CO}_{2}$ & $\mathrm{~N}_{2}$ \\
\hline $\mathrm{m}^{3} \mathrm{y}^{-1}$ & 8517 & 0.1 & 6567 & 1345 & 605 \\
\hline$\%$ & 100 & 0.002 & 77.1 & 15.8 & 7.1 \\
\hline $\mathrm{g} \mathrm{y}^{-1}$ & $7.6 \times 10^{6}$ & 124 & $4.4 \times 10^{6}$ & $2.5 \times 10^{6}$ & $7 \times 10^{5}$ \\
\hline
\end{tabular}




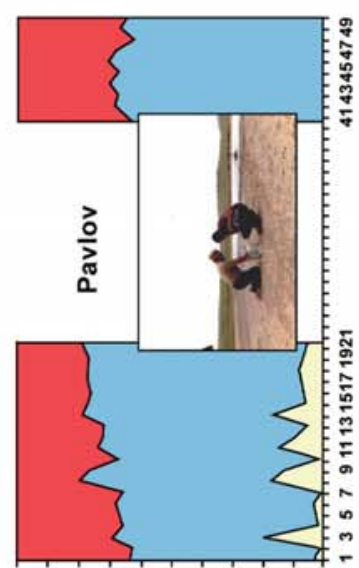

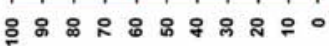
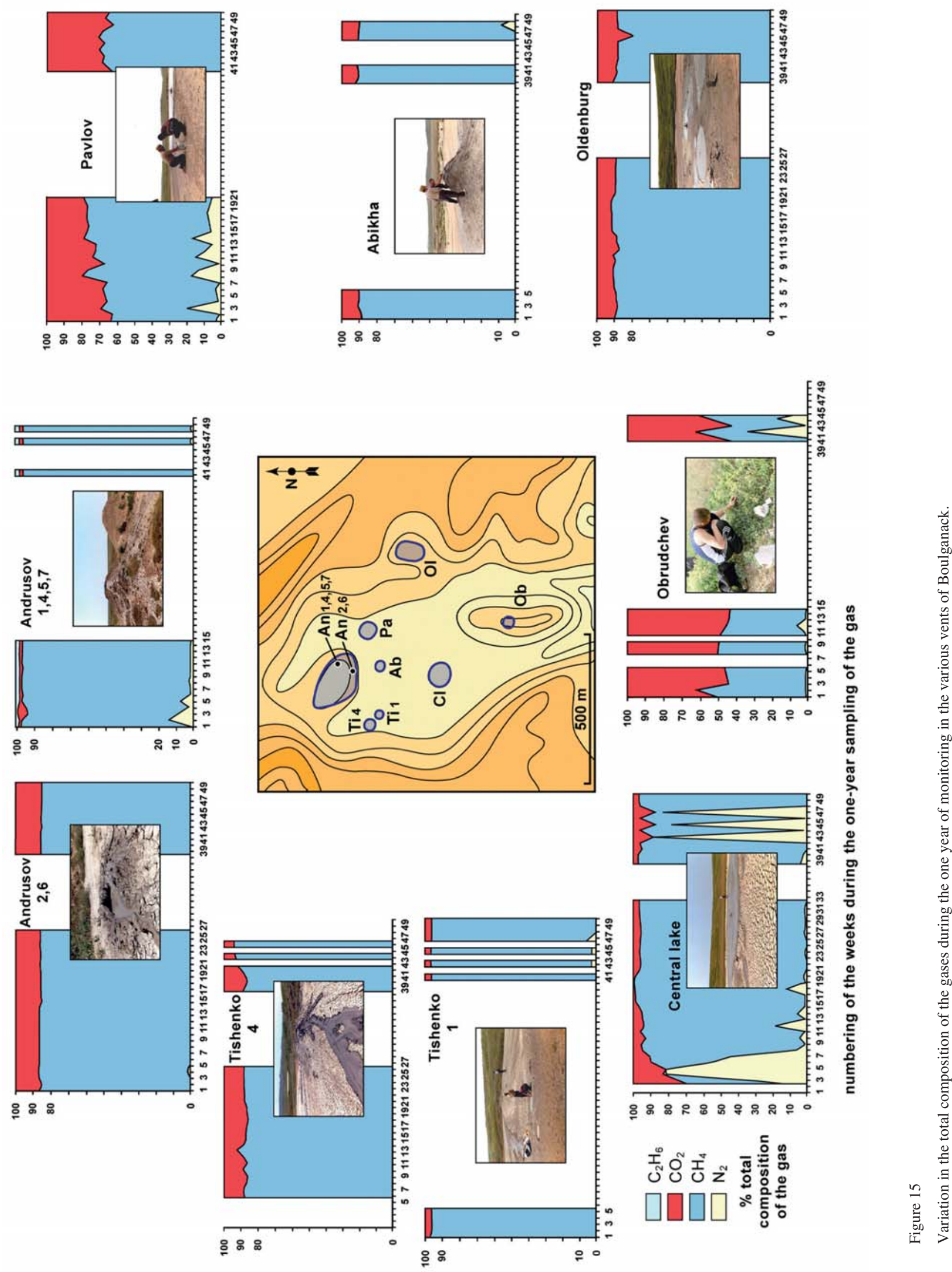
Most of the vents present a carbon isotopic ratio of methane ranging from -37 to $-40 \%$, which are typical values for thermogenic methane produced by thermal decomposition of the organic matter in the deep formations [8]. Carbon dioxide is mainly generated by thermal decomposition of carbonate rocks and not mantle-derived [9].

The vent-flux, deduced from the bubble diameter and bursting frequency, is highly variable according to the type of gryphon.

The higher outflow of gas in the Boulganack mud volcano occurs from the salses i.e. Pavlov and Central Lake, and to a lower extent in the Oldenburg pools. A lower outflow of gas is produced by the bubbling at the top of the cone shapes of Abihka and Tischenko. Around the main vent of Andrusov, which extrudes mostly plastic mud without bubbling, very little gas escapes except from the satellite vents. Obrudchev is virtually dry.

Nearby, the gas which escapes from the various vents, the disseminated micro-seepage also has to be taken into consideration. The pervasive micro-seepage flux from the soil surrounding the mud volcano is a fundamental component of the total gas output and can be estimated in the range of $0.1 \mathrm{~g} \mathrm{~m}^{2} \mathrm{~d}^{-1}[10]$. Considering that the Boulganack mud volcano occupies an area of about $1 \mathrm{~km}^{2}$ (not taking into account the area covered by ancient mud breccias), the total gas output by the disseminated micro-seepage would be in the range of $36.5 \times 10^{6} \mathrm{~g}$ per year. So the "invisible" contribution would be about five times higher than the "visible" gas escaping through the vents. The total emission for Boulganack would thus be estimated at 44 tons per year of dry gas composed of $77 \%$ methane, $16 \%$ carbon dioxide, $7 \%$ azote and very little ethane.

Four types of activity generally characterise the evolution in time of the mud volcanoes:

- Type 1: short and fierce explosion with a very high column of gas burning and a great volume of mud ejected,

- Type 2: eruption of breccias without explosion of gas, which means that the conditions are not favourable to a spontaneous combustion of the gas due to its composition or the speed of the ejection,

- Type 3: slow extrusion of plastic mud covering a large surface and producing a high volume of solid material,

- Type 4: continuous mud flow from various types of vents (dome, salse) lasting years.

During the monitoring study in the years 2000 to 2002, the Boulganack mud volcano had only an activity of types 3 and 4 , with a total production of $\mathrm{CH}_{4}$ from the various vents which can be estimated at $6500 \mathrm{~m}^{3} /$ year and $1300 \mathrm{~m}^{3} /$ year of $\mathrm{CO}_{2}$. Nevertheless, activity of type 2 is also known from the explosion on 1st September 1986, but no recent activity of type 1 has been reported.

Activity of type 1, i.e. with explosion and gas burning is, however, well known in nearby mud volcanoes of the Kerch Peninsula.

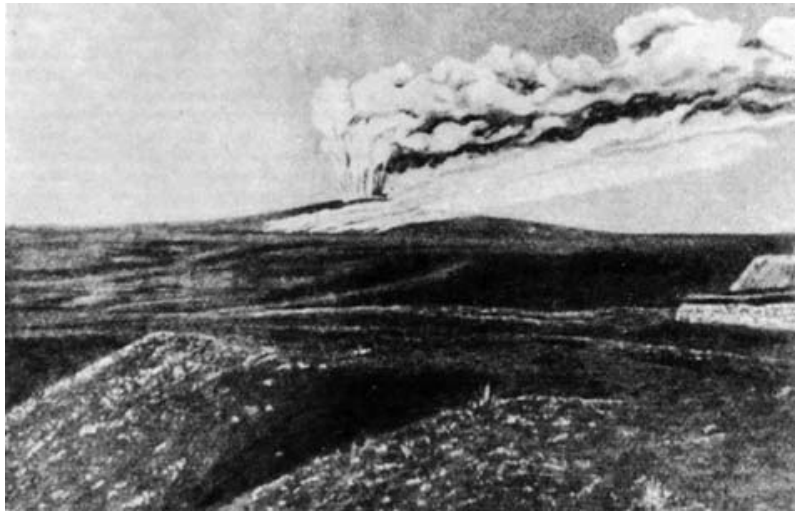

Figure 16

Eruption of the Dzau-Tepe mud volcano in 1914 by Shteber [6].

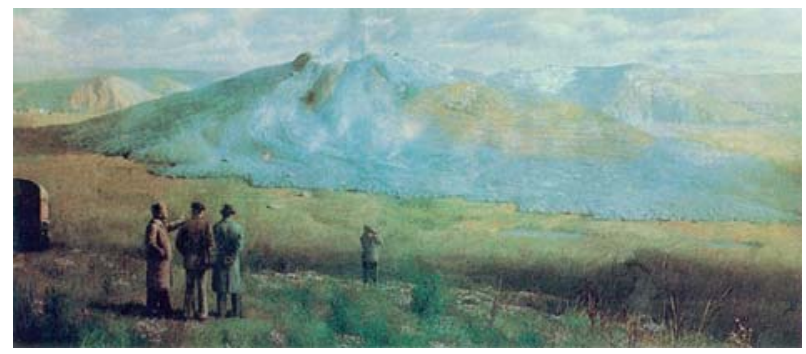

Figure 17

Eruption of the Dzhardzhava mud volcano painted by V.I. Kantemirov [6].

Catastrophic eruption of the Dzau-Tepe mud volcano (N 4509'00.8", E 35'55'49.4", see location in Fig. 3), which means "enemy top" in the Turkish language, occurred in March and August 1909 and more violently in March 1914 (Fig. 16). Mud was tossed 40-60 m up. Later in 1925, 1927 and 1942, mud volcanoes erupted many times but not so catastrophically. We must also keep in mind the legend of the awful eruption at the beginning of the XVIIth century, when the erupting mud destroyed a settlement.

In 1930, the Dzhardzhava mud volcano (N 4520'21.9', E 36 25'01.7": see location in Fig. 3), which means in Turkish "enemy's ravine", located $2 \mathrm{~km}$ west-south-west of Kerch, erupted with a mud flow of about $500 \mathrm{~m}$ in length and a burst of smoke and fire lasting 15 minutes (Fig. 17). The mud volcano breccias were oil-stained and leaking gas for a long time. In the spring of 1982, new explosions happened, bringing more than 100000 cubic $\mathrm{m}$ of mud to the surface, with eruptions up to $10 \mathrm{~m}$ high.

On the other side of the Kerch Strait, the activity of the mud volcanoes in the Taman area is also characterised by catastrophic explosions, burning for several hours a huge 
quantity of gas accumulated and sealed by a mud plug during a long period of time (often several decades, depending on the periodicity of the explosive phases).

Four hours before the explosion, when geologists visited the site of the Karabetova mud volcano (RussiaN 45 12'16" - E 36 47'05" - see location in Fig. 3) on 6th May 2001, no forewarning signs could be observed. Two months later, when we visited the site with Russian geologists, no sign of gas or water emissions could be observed, except for the slow extrusion of mud from the main crater.
The explosion produced impressive marks with a system of hectometre cracks characterised by a width of more than a metre and a depth often exceeding $3 \mathrm{~m}$ (Fig. 18). The excreted lumps of mud, thrown out and weighing tons, had preserved their grey colour or been transformed into "brick" when burned by the gas. After an explosion, as soon as the mixture of air and methane is in proportions of 5 to $15 \%$ of the gas, the baiting of the ignition can either be caused by the production of sparks, due to the shocks between the fractured and erupted rocks at the surface and, for example, marcassites
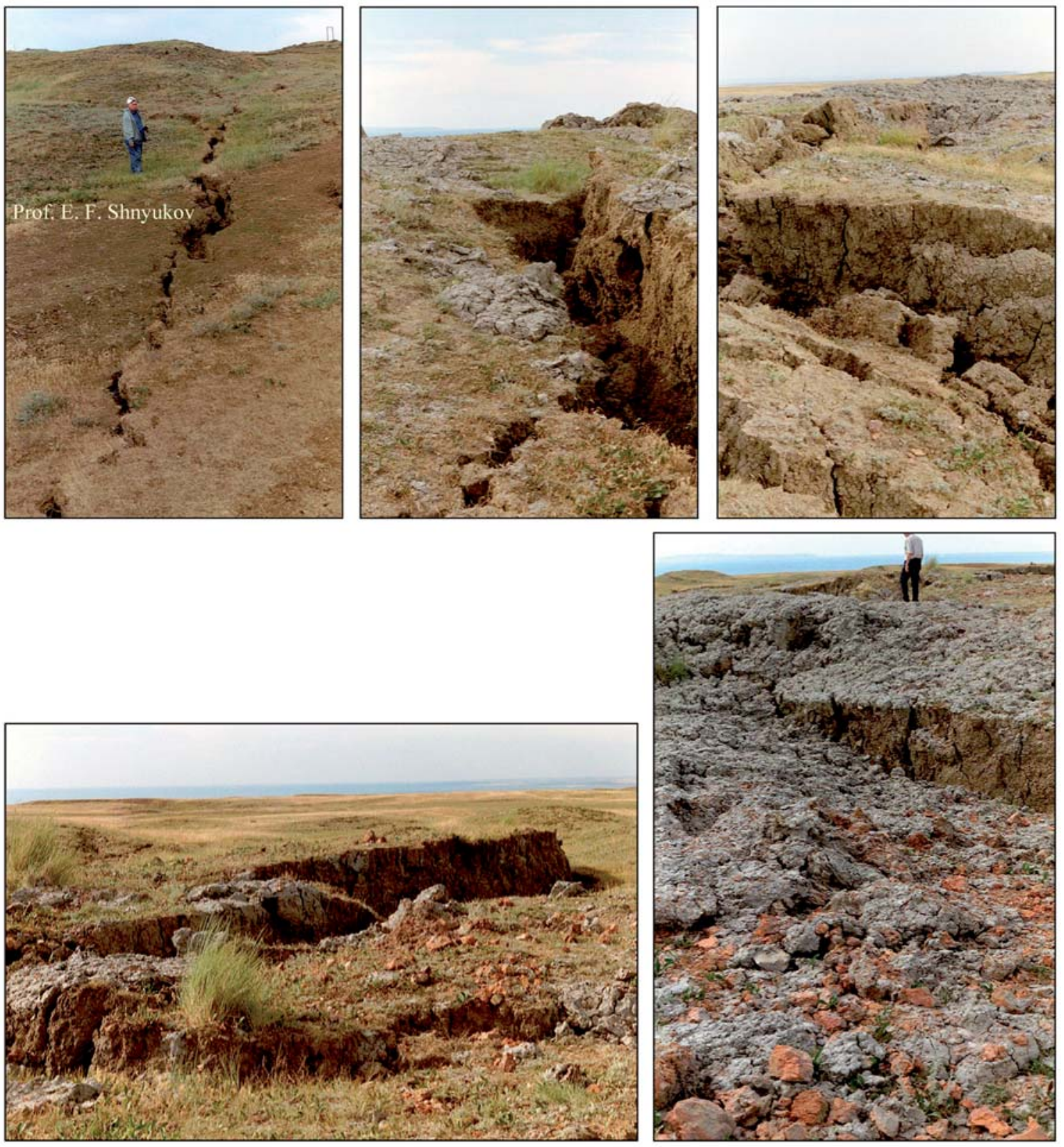

Figure 18

Fissuring observed two months after the explosion of the Karabetova mud volcano (Russia), which occurred on 6th May 2001. 
or pyrites, or by the spontaneous ignition of the mixture of the gases compressed by the shock wave of the explosion (the temperature of spontaneous ignition for methane being about $550^{\circ} \mathrm{C}$ ). Such explosions are comparable with the Unconfined Vapour Cloud Explosion (UVCE) which can be modelled with Computational Fluid Dynamics models [11].

The Lok-batan mud volcano - which means "drowning camel" - (Azerbaijan N 40¹8'16.8”, E 4942'32.6”) is renowned for its impressive eruptions [12, 13].

At least 19 eruptions have occurred since those of 1828 : 1864, 1887/major one, 1890, 1900, 1904, 1915, 1918, 1923, 1926, 1933, 1935/major one, 1938, 1941, 1954/major one, 1959, 1972, 1977, 31st March 1980 and 25th October 2001/major one [14-18].

Hjalmar Sjögren, geologist who worked with the Nobel Brothers near Baku, related one of the more intensive explosions which occurred on the night between January 5th and 6th 1887: "The first eruption, which took place shortly after 11:30 p.m., was followed by a somewhat less violent one at midnight, and a third one about 15 minutes later. The ball of fire was about 75 meters high, full of clumps of mud, stones and burning gases. Also, a lot of mud flowed out, not erupting so high up. Gradually, the flames and the heat lessened to a more steady rate which lasted until 5 o'clock in the morning", [19].

The more recent eruption, which occurred on the 25th October 2001, was comparable, as mentioned by the BBC's Clare Doyle: "There was a big explosion, and a huge flame started coming from the hillside. The flame was about three hundred metres high. It was surrounded by dense black smoke, and lots of mud was being thrown into the air. The biggest flames burned for about five minutes. Then there was another huge explosion, and then they calmed down about 10 or $20 \mathrm{~m}$ high. The flames could be seen from $15 \mathrm{~km}$ on the day of the explosion and were still burning, although at a lower level, three days later" (Fig. 19).

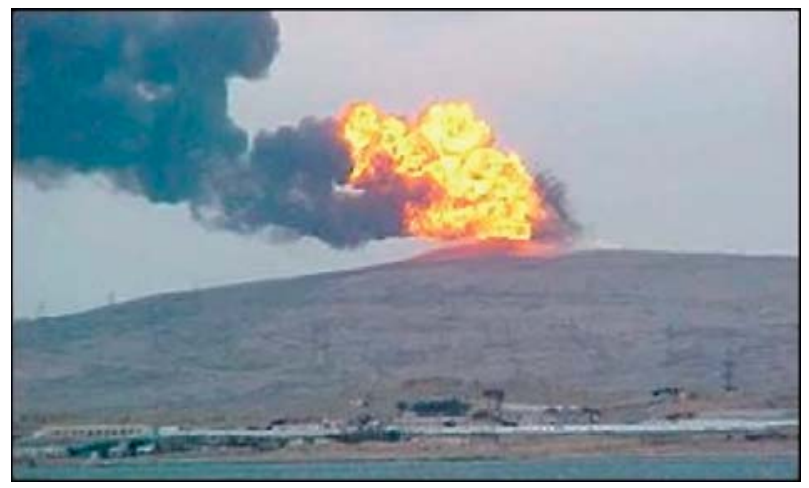

Photo Phil Hardy / from BBC NEWS 29th October 2001, Clare Doyle in Baku.

Figure 19

Eruption of the Lok-batan mud volcano in Azerbaijan on 25th October 2001.

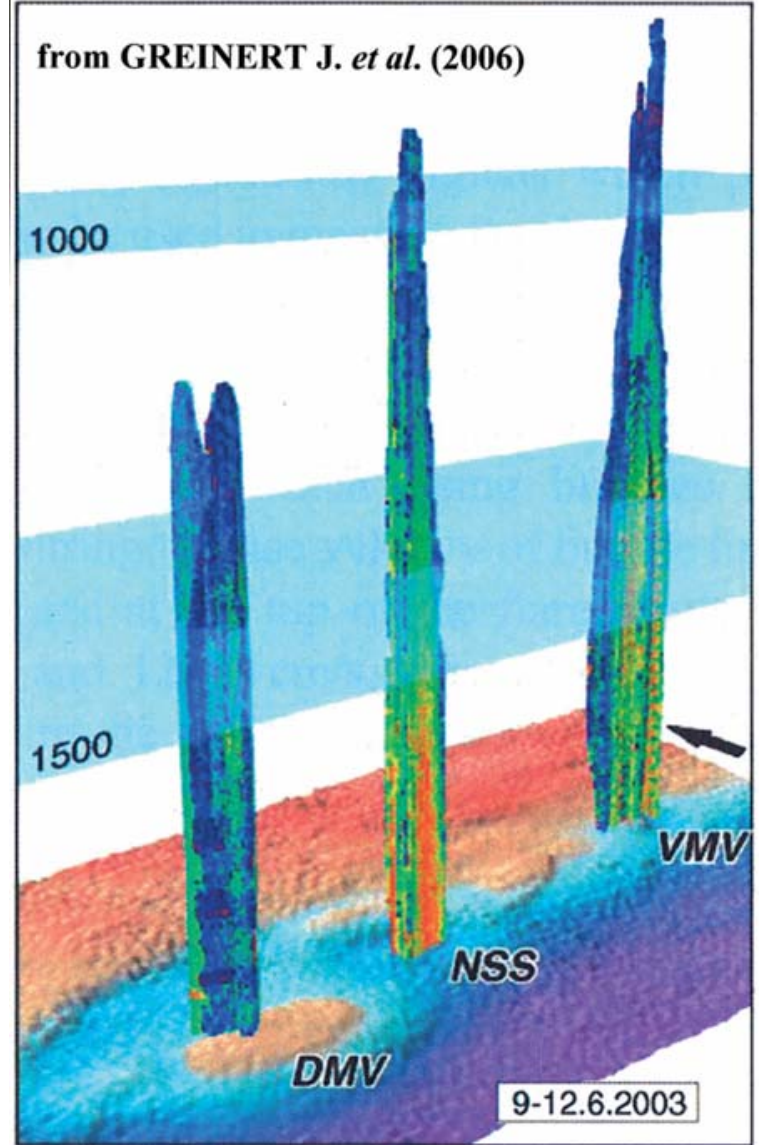

Figure 20

Typical echograms recorded in June 2003 [23], from the mud volcanoes in the Sorokin Trough (Dvurechenskiy mud volcano /DMV, Nameless Seep Site /NSS \& Vodyanitskiy mud volcano /VMV), blue plains are in the 1500 and $1000 \mathrm{~m}$ water depth, the black arrow points towards north.

According to the data issued from the mud volcanoes of Azerbaijan $[13,20]$ the volume of gas produced during such an explosive phase is in the order of magnitude of $120 \times 10^{6} \mathrm{~m}^{3}$ (i.e. $8 \times 10^{10} \mathrm{~g}$ if we consider that the gas is only methane), and the gas produced after such a phase by the projected breccias is estimated at $2 \mathrm{~cm}^{3}$ per kilogram, which represents a few thousand $\mathrm{m}^{3}$ of gas. In the Dashgill mud volcano (Azerbaijan N 3959'48.6”, E 49³2'13.8') a vent flux reaching $40 \times 10^{3} \mathrm{~m}^{3}$ was measured just after an eruption. Several weeks later it was at $8 \times 10^{3} \mathrm{~m}^{3}$ and after a year, according to the same authors, it stabilised at $200 \mathrm{~m}^{3}$ day in this particular mud volcano.

Thus, the volume of gas escaping during the explosive phases is far higher than that produced daily during the mud volcano's period of quiescence (80 000 tons instantaneously compared to the 40 tons/year produced in the case of Boulganack). Every mud volcano is a particular leakage 
point and the volume exhausted yearly depends on the sealing property of the mud, the design of the chimneys, the connection with a deep source of material, with or without fracturation, etc. But the daily, monthly and yearly escape of gas by a mud volcano is not representative of the global quantity of gas discharged in the atmosphere if we do not take into consideration the quantity of gas produced during the explosive periods, i.e. the catastrophic events [21].

Mud volcanoes also exist offshore the Kerch Peninsula, in the Black Sea, as described in the TTR 11 cruise [22]. They are identified by hydroacoustic plumes. The outflow of the gas on the mud volcano onshore can be compared with the methane bubbling (i.e. free gas-releasing) cold seeps which are identified by hydroacoustic plumes in the water column. In the Sorokin Trough (location in Fig. 3), southeast of the Indolo-Kuban Basin, regular observation deduced from hydroacoustic surveys at different periods of time [23] on the Dvurechenskiy mud volcano (DMV), Nameless Seep Site (NSS) and Vodyanitskiy mud volcano (VMV) also indicate a variation in the activity of these mud volcanoes with periods of intense high flares (Fig. 20).

\section{RESULTS OBTAINED FROM THE MUD SAMPLES TAKEN IN THE VENTS OF THE MUD VOLCANOES}

The mud samples contain different kinds of information, deduced from classical geochemical study. The kerogen included in the mud is representative of the geological formation where the mud volcanoes take root. As a consequence, it is indicative of the type of organic matter related to the quality of the potential source rocks underneath.
The concentration of kerogen being diluted within the whole volume of the outflow of mud, parameters such as the percentage of Total Organic Carbon (TOC) or the petroleum potential (S2 peak) issued from the Rock-Eval analysis [24] must not be interpreted in the same manner as the classical samples taken on the outcrops.

On the field, the alternation of the sedimentological facies causes a fluctuation of the geochemical parameters (TOC, S2) which are easy to interpret yet do not exist in the mud.

The source rocks related to the Maykop formation (Oligo-Miocene), from samples (wells or outcrops) taken from Azerbaijan and from the Kerch Peninsula, have different petroleum potential (Fig. 21). In Azerbaijan the source rocks have values of S2 of Rock-Eval which often overstep $20 \mathrm{~kg} \mathrm{HC} /$ ton of rock and even reach up to $120 \mathrm{~kg} \mathrm{HC} /$ ton of rock. In contrast, most of the samples from the Kerch Peninsula rarely overstep $2 \mathrm{~kg} \mathrm{HC} /$ ton of rock which is considered as the minimum value for a potential source rock. Concerning the total organic carbon (TOC): in Azerbaijan the TOC can reach up to $20 \%$ and in the Kerch Peninsula the highest value of TOC in the Maykop formation is about $7 \%$ (Fig. 22). These differences reflect the variation in the paleogeographic framework when, during the Oligo-Miocene period, the deposition of aquatic organic matter was more favourable in the eastern part of the Caucasus (Azerbaijan, Caspian Sea) while terrestrial organic matter was preserved on the edge of the Scythian platform [25].

Considering the same geochemical parametres contained within the muds sampled in the mud volcanoes of these two provinces sampled in 2000 and 2001 [26, 27], there are no significant differences - which means that TOC and S2 are
Maykop source-rocks (rock samples): TOC versus S2

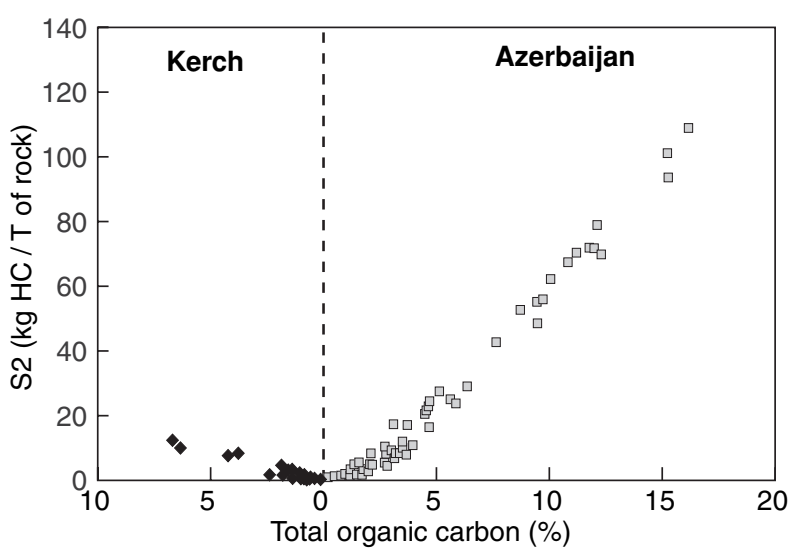

Figure 21

TOC versus $\mathrm{S} 2$ in the field samples of the Maykop Formation. Comparison between the Kerch Peninsula and Azerbaijan.
Mud (samples extracted by dichloromethane): TOC versus S2

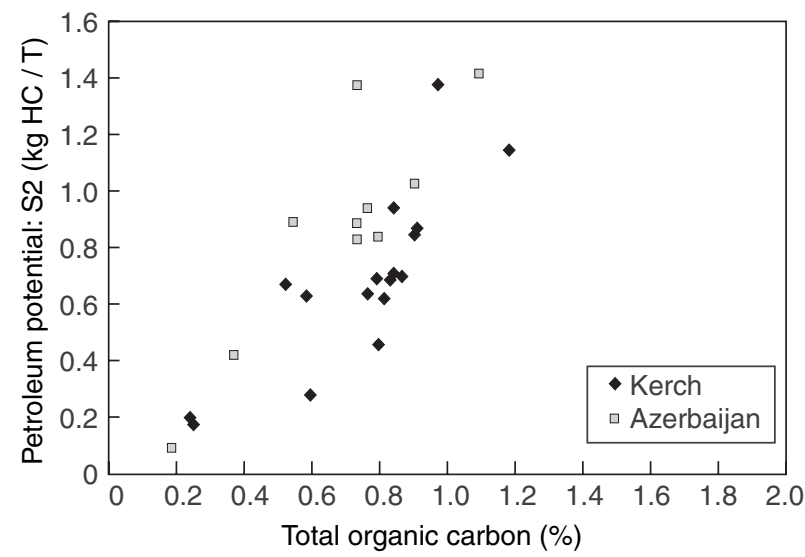

Figure 22

TOC versus $\mathrm{S} 2$ in the mud volcano samples: comparison between the Kerch Peninsula and Azerbaijan. 


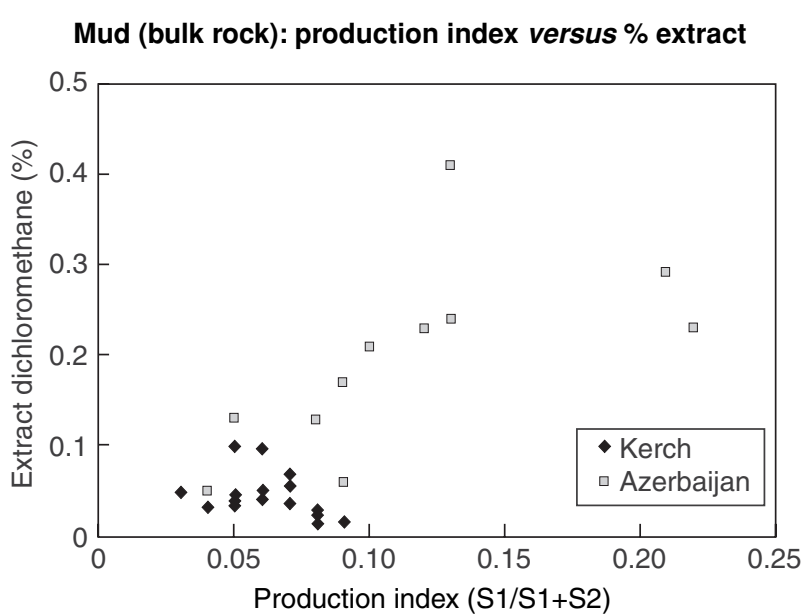

Figure 23

Quantity of free hydrocarbon in the mud, comparison between mud volcano samples in the Kerch Peninsula and Azerbaijan

not discriminating factors for the mud samples (Fig. 22), and do not allow us to identify accurately the potential of the source rocks beneath due to the dilution of the kerogen within the volume of mud.

However, other information obtained from the mud includes the quantity of free hydrocarbons, which characterises the efficiency of the petroleum system and the ability of the source rocks to generate oil and gas.

Two kinds of analyses give information concerning the petroleum system beneath:

- the quantity of free hydrocarbons in the mud samples determined by the peak S1 of the Rock-Eval and/or the quantity of extract resulting from a leaching of the mud sample with a solvent (dichloromethane),

- the chromatographic analysis of this extract, which allows us to identify the origin of the organic matter (marine versus terrestrial).

The comparison of the quantity of hydrocarbons included in the mud released from the mud volcanoes of the Kerch Peninsula and those of Azerbaijan clearly shows that there are very few free hydrocarbons in the mud from the mud volcano in the Crimea, although accumulations of hydrocarbons exist in the fluids expelled from the same structures in Azerbaijan (Fig. 23).

Analysis by chromatography of the saturated hydrocarbons shows:

- a high degree of biodegradation when the sample is taken at the surface, which is the case in the narrow gryphons where the core barrel cannot be used at depth, e.g. in the Samoiylov mud volcano/Kerch Peninsula with $0.10 \%$ extract (Fig. 24),

- or a perfect chromatogram for the samples taken with the core barrel at a greater depth, e.g. $17.5 \mathrm{~m}$ at the Boulganack mud volcano in the Oldenburg vent, even if the percentage of extract is very low: 0.01 . Due to the absence of biodegradation, the distribution of the $\mathrm{N}$ alcanes presents an imparity in C25, C27 and C29, and a continental origin of the organic matter can be inferred for this sample (Fig. 25).

The chromatograms of the saturated hydrocarbon can also be compared with those of field samples taken from the outcrops of the Maykop formation in the Kerch Peninsula, north of Feodocia city (Fig. 26). They also show a great imparity in nC23, C25, C27, C29 and C31. The quantity of total organic carbon is higher in the field samples, $1.4 \%$ to $3.5 \%$, because, unlike in the mud, the kerogen is not diluted.

\section{KERCH-SAMOIYLOV}

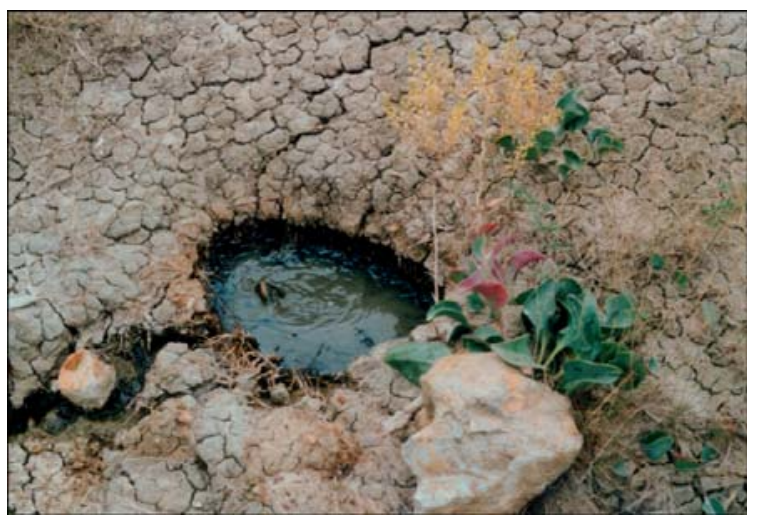

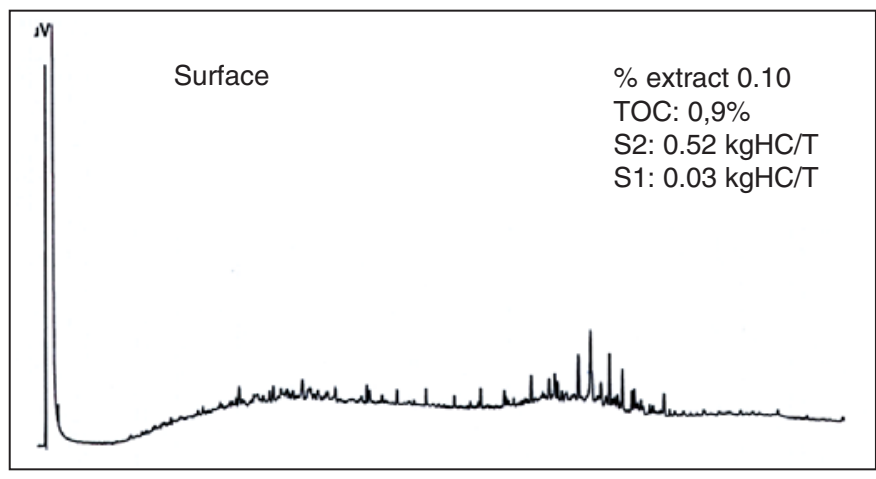

Chromatogram of saturated hydrocarbons

Figure 24

Chromatography of the hydrocarbons in a sample taken at the surface: Samoiylov mud volcano. 
KERCH-BOULGANACK - Oldenburg vent
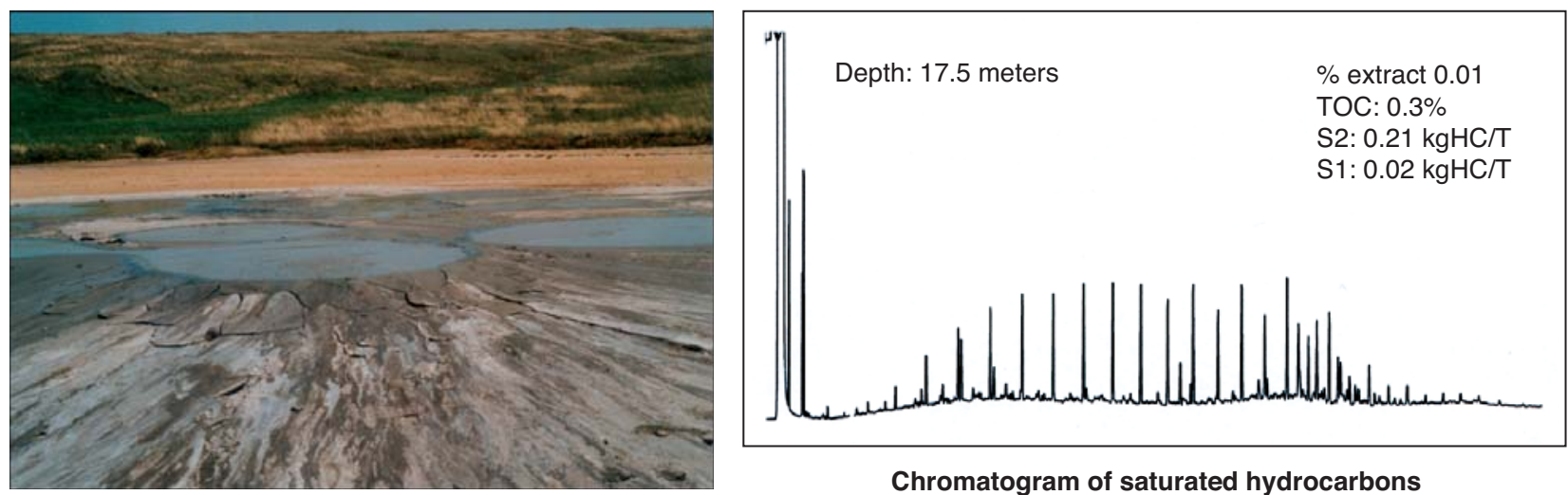

Figure 25

Chromatography of the hydrocarbons contained in a sample taken with the core barrel at great depth $(17.5 \mathrm{~m})$ in the Oldenburg vent of the Boulganack mud volcano.
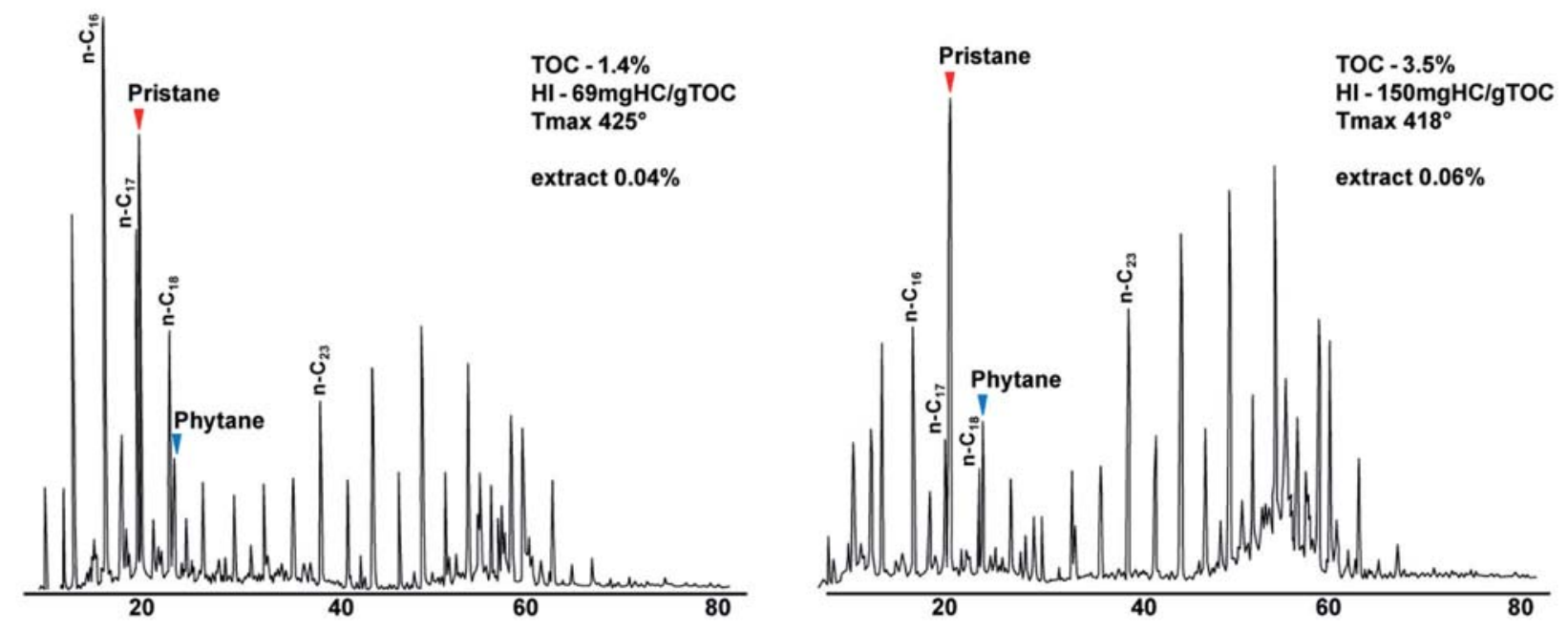

Figure 26

Chromatograms of saturated hydrocarbon from field samples of Maykop in the Kerch Peninsula.

The mud coming from different geographic areas well known for their high mud volcano activity: Trinidad, Azerbaijan, Taman, Kerch, Sicily, and Makran, presents a great range of variation in the content of free hydrocarbons. Whatever the area, all the samples of mud were exclusively taken with the same methodology of the core barrel at the maximum depth in the vents. The richness in free hydrocarbons for these samples is shown in Figure 27: on the abscissa $\mathrm{S} 1 R B$, which is the $\mathrm{S} 1$ peak of the Rock-Eval analysed from the bulk sample, plus $\{\mathrm{S} 2 R B-\mathrm{S} 2 R D\}$, which represents the difference between the peak $S 2$ obtained on the bulk sample $(=R B)$ and then after extraction with dichloromethane $(=R D)$, i.e. the part of the signal of the Rock-Eval which does not correspond to kerogen sensu stricto; in ordinate the \% extract is the quantity of hydrocarbon from classical dichloromethane extraction. The petroleum provinces of Trinidad and Azerbaijan clearly outpass the other provinces; Kerch is in the third position. Thus, the ranking of the petroleum provinces appears obviously linked to the occurrence of free hydrocarbons in the mud excreted. And the study of free hydrocarbons in the mud volcanoes can allow us to standardise the petroleum provinces. This can be particularly interesting in the frontier areas and high prospectivity zones in terms of petroleum exploration. 


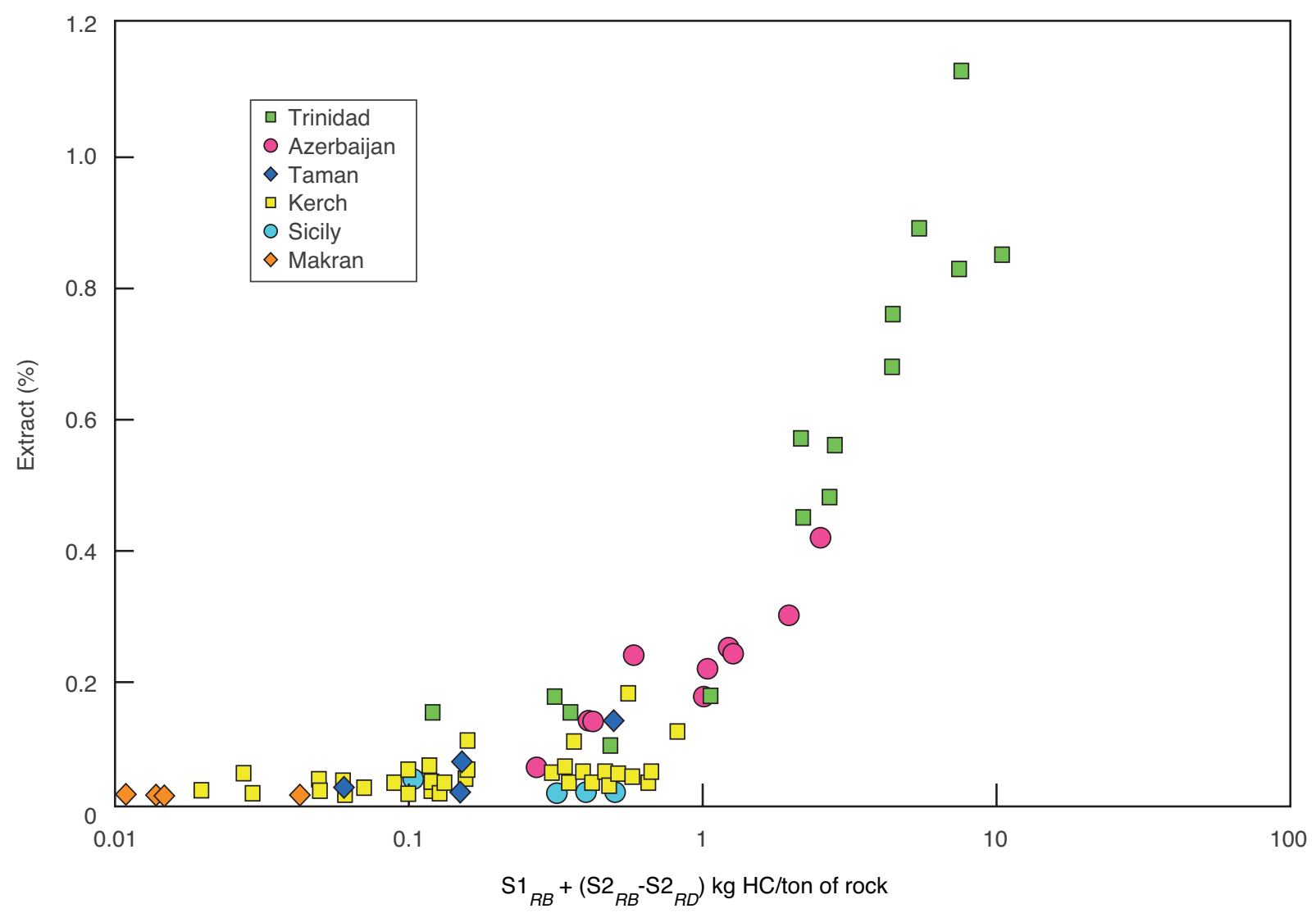

Figure 27

Content of free hydrocarbons analysed in the mud, sampled exclusively from the core barrel at the maximum depth of the vents, in different provinces well-known for their mud volcano activity.

\section{MODELLING OF THE HYDROCARBON WINDOW GEOHISTORY}

In relation to the origin of the hydrocarbons in the mud, the hypothesis of the generation of hydrocarbons from the Maykop series on both sides of the Kerch Strait has been tested, based on the geothermal studies [28], the evaluation of the oil and gas potential of the Maykop series of the IndoloKuban basin [29] and the Kerch-Taman structuration related to the hydrocarbon generation [30].

In this study the results from the indices of maturity based on the Tmax of the Rock-Eval were used and combined with GENEX software in order to relate the hydrocarbon window geohistory.

In the Kerch Peninsula, at the present time, the Maykop is located deeper than 2.5 kilometres. It has reached a stage of maturity close to the oil window, corresponding to a vitrinite reflectance above 0.7 (Fig. 28). At this early stage of maturity the production of hydrocarbons is, however, not completely efficient for terrestrial organic matter (type III), which requires more energy than aquatic organic matter (type II) to produce hydrocarbons. The generation of oil is also relatively limited, partly due to the type of the source rocks, which belong to terrestrial origin and are mainly gasprone. On average, the petroleum potential reaches $1.5 \mathrm{mg}$ hydrocarbons per gram of rock (or kilo of HC per ton of rock) in the Fontanovka- 8 and Boulganack-1 petroleum wells (Fig. 29).

The base of the Maykop belongs to the oil window (vitrinite reflectance fluctuates between 0.7 and 1.0) from the lower Miocene, and due to the mainly type III organic matter (terrestrial origin), the genesis of the hydrocarbons starts moving only around $12 \mathrm{Ma} \mathrm{BP}$, i.e. during the middle Miocene (Fig. 30). 

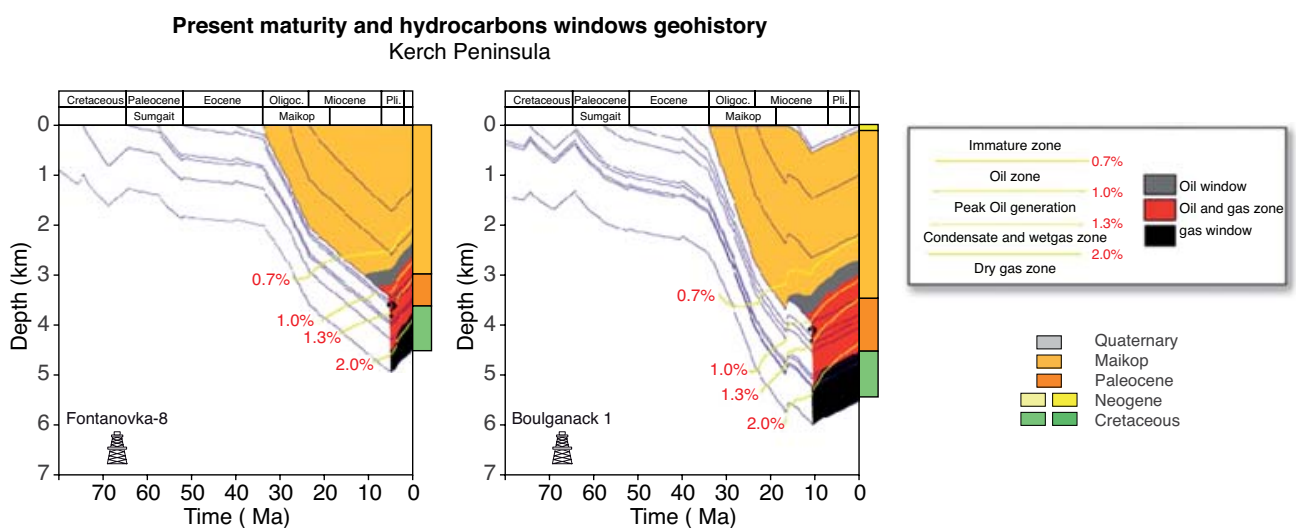

Figure 28

Present thermal maturity of the source rocks from the Kerch Peninsula.

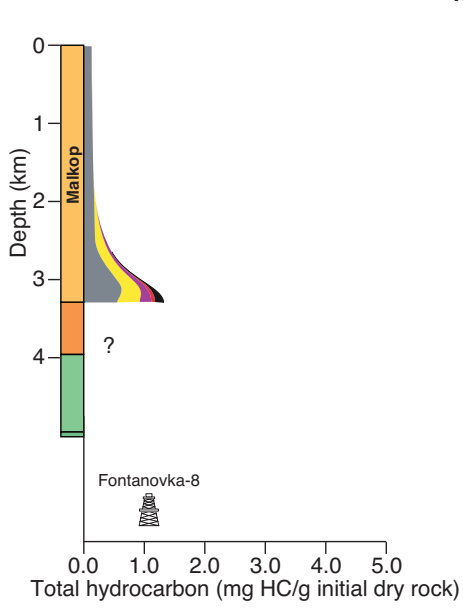

Wells state total hydrocarbons
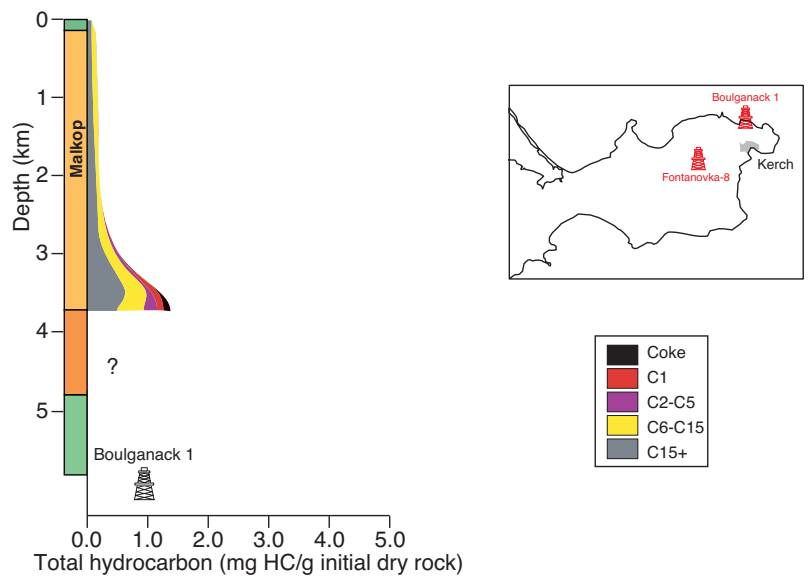

Figure 29

Modelling of the genesis of the hydrocarbons in the Kerch Peninsula from Fontanovka-8 and Boulganack-1 drillings.
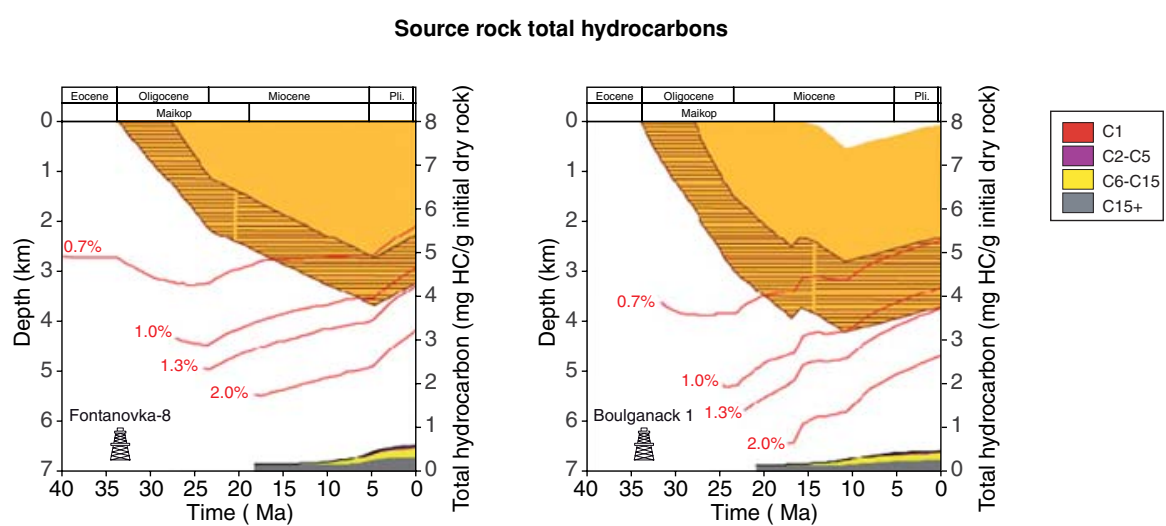

Figure 30

Thermal history of the Maykop deposit in the Kerch Peninsula. 


\section{CONCLUSION}

Mud volcanoes act as very powerful prospecting indices in the exploration of oil and gas deposits. Geochemical samples of mud issued from the mud volcanoes give information about the petroleum system beneath, provided that they are not oxidised or altered by microbiological activity.

The quantity of free hydrocarbons and their origin allow us to evaluate the petroleum potential of the provinces, between an oil province with a classical type II marine organic matter or a gas province with a terrestrial origin (type III). The ranking of the petroleum provinces is linked to the occurrence of the free hydrocarbons in the mud excreted.

In the same manner, the methodology applied to the deep offshore mud volcanoes would allow us to evaluate the potential of the petroleum system beneath. Further information about future prospecting in the deep offshore will depend on the ability to take samples devoid of any alteration/oxidation processes at the bottom of the sea floor and to characterise quantitatively and qualitatively the organic compounds which exist in the mud.

In the Kerch Peninsula the organic matter in the mud and that released from the kerogen in the field samples belong to the type III origin. Consequently, the petroleum potential of the source rock would remain rather a gas province for this area. Offshore, toward the Black Sea, this approval could be qualified if the organic facies of the Maykop was similar to those existing in the Kuban area with a type II origin, i.e. oil-prone.

The main types of gas produced by the Boulganack mud volcano are methane and carbon dioxide. The variation in the the gas exhausted depends from one vent to another, but there is little variation in time, either in quantity (outflow) or quality. Such a detailed study provides reference data for the quantification of the geologic source of fossil hydrocarbon gases and $\mathrm{CO}_{2}$ to the atmosphere during the quiescent period (years to centuries). However, the quantity of gas generated by the eruptive periods (hours to days) makes it more difficult to estimate the global gas flux in the atmosphere.

\section{BY WAY OF AN EPILOGUE}

Location: Sidoarjo, Surabaya, East Java. 28th May 2006: date of the beginning of the extrusion of the mud. The origin of the extrusion was connected with a drilling originally looking for gas production (methane).

Outflow of mud during the first days: $5000 \mathrm{~m}^{3} /$ day! Outflow of mud in November 2006: $50000 \mathrm{~m}^{3} /$ day!

Temperature of the $\mathrm{mud}: 60^{\circ} \mathrm{C}$.

Gas associated: $\mathrm{H}_{2} \mathrm{~S}$.

50 square kilometres covered by the mud!

Displaced people by the thousand!

Still in activity in December 2007.

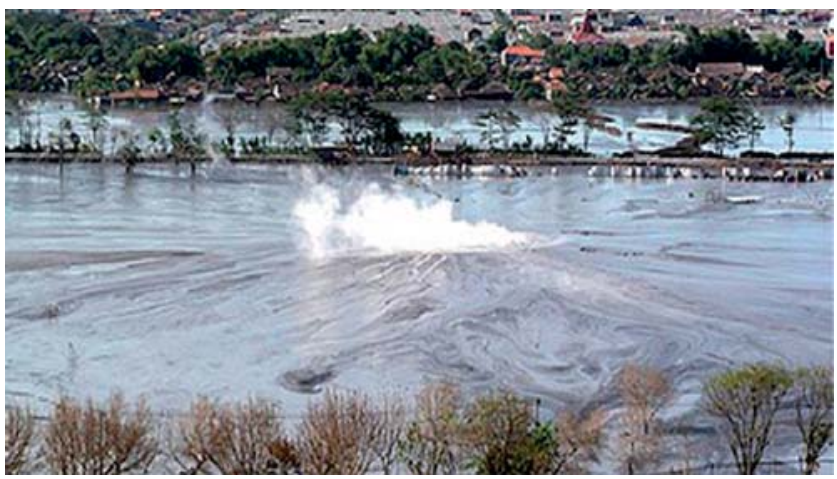

\section{ACKNOWLEDGEMENTS}

The authors thank Maxim Vitchnievski and Leonid Joukov who carried out the one-year monitoring, taking the gas samples every week, between June 2001 and June 2002. Nikolaï Maslakov carried them regularly to Kiev before they were sent to IFP for analysis. We also thank Galina Alaoui for her involvement in the success of the mission on the field in June 2001 and March 2002, and M. Topatchevsky for his administrative contribution. Last but not least, we thank all the team in Kiev and Kerch who made this monitoring possible.

At IFP, the analyses of the gas were done by Claudette Leblond, Sonia Noirez, Sébastien Esnault and Jérémie
Ferrand under the supervision of Alain Prinzhofer and Anne Battani; the analyses of the mud were done by Gérard Caillet.

The authors thank Bernard Colletta, who made this study possible, the anonymous referees for their fruitful remarks, and Michael Price for improving the English.

Jean-Paul Herbin also thanks Henri Pétraszko who helped him to build "the Herbinette", i.e. the core barrel, allowing us to sample mud at the deepest bottom of the vent.

In Trinidad, Azerbaidjan, Kerch and Taman the samples of mud were taken in the vents by the authors, and in Sicily and Makran by two colleagues from IFP: Nadine Ellouz and Eric Deville, with the same core barrel. 


\section{REFERENCES}

1 Gueramisov M.E. (1991) Thrust dislocation and clay diapirism in lower Cretaceous deposits in Indolo-Kuban (in Russian), Geologia nefti i gaza 2, 89-95.

2 Gueramisov M.E. (1992) Tectonic of Mesozoic deposits and diapirs of the Kerch Peninsula (in Russian), Geologia nefti $i$ gaza 2, 15-19

3 Ozernii O. (1981) Regularities of distribution of the over pressured layers in Southern Ukraine, Geol. Oil Gas 6, 50-56 (in Russian).

4 Gorshkov A.S., Meisner L.B., Soloviev V.V., Tugolesov D.A., Khakhalev E.M. (1989) Album of Structural and Thickness maps of Black Sea Basin Cenozoic Sediments, Scale 1/1500000, Tugolesov D.A. (Ed.), Main Administration of Geodesy and Cartography under the USSR Council of Ministers, USSR Ministry of Geology - Yuzhmorgeologiya - Scientific Reseach and Design Institute of Geophysical Methods for Ocean Exploration - Gelendzhik (in Russian).

5 Shnyukov Ye.F., Sobolevskiy Yu.V., Gnatenko G.I., Naumenko P.I., Kutniy V.A. (1986) Atlas des volcans de boue de la province de Kerch-Taman, Naukova Dumka, 151 p.

6 Shnyukov Ye.F., Gnatenko G.I., Nesterovskiy V.A., Gnatenko O.V. (1992) Volcans de boue de la province de Kerch-Taman Pechora, Naukova Dumka, 200 p.

7 Dimitrov L.I. (2002) Mud volcanoes - The most important pathway for degassing deeply buried sediments, Earth Sci. Rev. 59, 49-76.

8 Ferrand J., Battani A., Boulègue J., Herbin J.P., Prinzhofer A. (2003) Crimea's mud volcanoes: a one year geochemical monitoring. Geophysical Research Abstracts, Vol. 5, 09740.

9 Ferrand J. (2007) Dynamique des systèmes de volcans de boue, Thèse de l'Université de Paris VI, Pierre et Marie Curie, $366 \mathrm{p}$.

10 Etiope G. (2005) Methane emission from mud volcanoes. Towards a global estimate, in Mud Volcanoes, Geodynamics and Seismicity, Martinelli G., Panahi B. (Eds.), Springer, NATO Science Series IV Earth and Environmental Sciences, Vol. 51, pp. 141-146.

11 Mouilleau Y., Lechaudel J.F. (1999) Guide des méthodes d'évaluation des effets d'une explosion de gaz à l'air libre, Rapport INERIS, 166 pages.

12 Yakubov A.A., Ali Zade A.A. (1971) Mud Volcanoes of the Azerbaijan SSR, 258 p.

13 Guliyev I.S., Feyzullayev A.A. (1996) All about mud volcanoes. Geology Institute Azerbaijan Academy of Sciences, Jevanshir R.D. (Ed.), Nafta Press, Baku, 51 p.

14 Yakubov A.A., Ali Zade A.A., Rakhmanov R.R., Mamedov Yu.G. (1974) Catalogue of Recorded Mud Volcano Eruptions in Azerbaijan (1810-1974), Azerbaijan Academy of Sciences Publication, Baku, in: Appendix 1.2, Catalogue of Mud Volcano Eruptions in Azerbaijan, 1810-1992, Geol. Ins. Azer.

15 Rakhmanov R.R. (1992) Catalogue of Mud Volcano Eruptions recorded in Eastern Azerbaijan and the Caspian Sea from June 1974 to October 1992. Azerbaijan Academy of Sciences Publication, Baku, in: Appendix 1.2, Catalogue of Mud Volcano Eruptions in Azerbaijan, 1810-1992, Geol. Ins. Azer.

16 Etiope G., Feyzullayev A., Baciu C.L., Milkov A.V. (2004) Methane emission from mud volcanoes in eastern Azerbaijan, Geology 32, 465-468.
17 Aliyev A.D., Guliyev I.S., Belov I.S. (2002) Catalogue of recorded eruptions of mud volcanoes of Azerbaijan, Nafta Press, Baku, 89 p.

18 Martinelli G., Dadomo A. (2005) Mud Volcano monitoring and seismic events, in Mud volcanoes Geodynamics and Seismicity, Martinelli G., Panahi B. (Eds.), NATO Science Series, IV Earth and Environmental Sciences, Vol. 51, pp. 187-199.

19 Asbrink A., Rinman E. (2001) Ludvig Nobel: Petroleum Har En Lysande Framtid En Historia Om Eldfangd Olja Och Revolution I Baku (Ludvig Nobel: Petroleum Has a Bright Future), Wahlstrom \& Widstrand.

20 Sokolov V.A., Buniat-Zade Z.A., Goedekian A.A., Dadashec F.G. (1968) The Origin of Gases of Mud Volcanoes and their powerful Eruptions, in Advances in Geochemistry, Schenk P.A. and Havenaar I. (Eds.), pp. 473-484.

21 Milkov A.V., Sassen R., Apanasovitch T.V., Dadashev F.G. (2003) Global gas flux from mud volcanoes: a significant source of fossil methane in the atmosphere and the ocean, Geophys. Res. Lett.30, 2, 1037

22 Meisner L., Krylov O., Volkonskaya G.A., Cifci G., Onder S., Dondurur D., Elbek O.F., Bouryak S., Shkarinov S., Ogibalov S. Seismic profiles; Meisner L., Krylov O., Akhmetzhanov A., Shaskin P., Ivanov M., Cifci G., Onder S., Dondurur D., Elbek O.F. - Sonar; Akhmanov G., Mazzini A., Stadnitskaia A., Ivanov M., Ovsiannikov D., Sadekov A., Kozlova E., Blinova V., Torlov V., Poludetkina E., Tyrina N., Bespalova T., Kovalenko O., Sraelens P. - sampling and sedimentology. Geological processes in the Mediterranean and Black Seas and North East Atlantic. IOC Technical Series No. 62, UNESCO (2002) Preliminary results of investigations during the TTR-1 cruise of RV Professor Logachev July-September, 2001.

23 Greinert J., Artemov Y., Egorov V., De Batist M., McGinnis D. (2006) $1300 \mathrm{~m}$ high rising bubbles from mud volcanoes at 2080 $\mathrm{m}$ in the Black Sea: Hydro acoustic characteristics and temporal variability, Earth Planet. Sc. Lett. 24, 1-15.

24 Espitalié J., Deroo G., Marquis F. (1986) La pyrolyse Rock-Eval et ses applications, Revue de l'IFP 40, 5, 563-579, 40, 6, 755784 and $\mathbf{4 1}, 1,73-89$.

25 Saint-Germès M. (1998) Étude sédimentologique et géochimique de la matière organique du bassin Maïkopien (OligocèneMiocène inférieur) de la Crimée à l'Azerbaïdjan. Thèse de l'Université de Paris VI, Pierre et Marie Curie, 295 p.

26 Herbin J.P., Deville E., Prinzhofer A., Schneider F., Vially R. (2001a) Volcans de boue d'Azerbaïdjan. Rapport interne de l'Institut français du pétrole No. 55873,31 p.

27 Herbin J.P., Prinzhofer A., Saint Germès M., Vially R. (2001b) Compte rendu de la mission de terrain effectuée sur les volcans de boue de Kerch (Ukraine) et de Taman (Russie). Rapport interne de l'Institut français du pétrole No. $56258,40 \mathrm{p}$.

28 Matvienko V.N. (1968) Results of geothermal studies at the Kuban (in Russian), Geologia nefti i gaza 8, 15-18.

29 Petrischenko Y.A. (2000) Oil and gas potential of the Maykop series of the Indolo-Kuban basin (in Russian). Thèse de Doctorat de l'Université d'État de Moscou, $146 \mathrm{p}$.

30 Gavrilov V.P., Chainov P.V. (1992) Thrust structure of Kerch-Taman shelf and oil and gas occurrence (in Russian), Geologia nefti i gaza 2, 33-37.

Final manuscript received in December 2007 Published online in September 2008

\footnotetext{
Copyright (C) 2008 Institut français du pétrole

Permission to make digital or hard copies of part or all of this work for personal or classroom use is granted without fee provided that copies are not made or distributed for profit or commercial advantage and that copies bear this notice and the full citation on the first page. Copyrights for components of this work owned by others than IFP must be honored. Abstracting with credit is permitted. To copy otherwise, to republish, to post on servers, or to redistribute to lists, requires prior specific permission and/or a fee: Request permission from Documentation, Institut français du pétrole, fax. +33147527078 , or revueogst@ifp.fr.
} 